\title{
Role of reduced expression of SMAD4 in papillary thyroid carcinoma
}

\author{
Sonia D’Inzeo*, Arianna Nicolussi, Antonella Ricci, Patrizia Mancini, \\ Antonio Porcellini ${ }^{1}$, Francesco Nardi and Anna Coppa \\ Department of Experimental Medicine, Sapienza University of Rome, Viale Regina Elena, 324, 00161 Roma, Italy \\ ${ }^{1}$ Department of Health Science, University of Molise, Via F. De Sanctis, 86100 Campobasso, Italy \\ (Correspondence should be addressed to A Coppa; Email: anna.coppa@ uniroma1.it)
}

*(S D'Inzeo and A Nicolussi contributed equally to this work)

\begin{abstract}
It has been demonstrated that transforming growth factor- $\beta$ (TGF $\beta$ ) and other members of TGF $\beta$ superfamily play an important role in thyroid proliferative diseases. The deficiencies of SMAD4 are responsible to accelerate the malignant progression of neoplastic lesions in several types of tumors. Therefore, the objective of the present study was to determine the functional role of reduced expression of SMAD4 in human papillary thyroid carcinogenesis. For this purpose, we examined the TGF $\beta$ response in two cell lines, TPC-1 and BCPAP. Our data demonstrated for the first time that these cells showed a strong reduction in the level of SMAD4 protein, which was responsible for an alteration of TGF $\beta$ signaling and for some of the TGF $\beta$-mediated biological effects. The overexpression of SMAD4, restoring TGF $\beta$ transduction, determined a significant increase of antiproliferative response to TGF $\beta$, and reduced the invasive behavior of these cells. Therefore, our data indicated that reduction of SMAD4 may play a significant role in thyroid carcinogenesis.
\end{abstract}

Journal of Molecular Endocrinology (2010) 45, 229-244

\section{Introduction}

Transforming growth factor- $\beta$ (TGF $\beta$ ) belongs to a large superfamily of growth factors and controls a plethora of cellular responses, including cell proliferation, differentiation, motility, adhesion, extracellular matrix protein expression, apoptosis, and specification of developmental fate, during embryogenesis as well as in mature tissues, in species ranging from flies and worms to mammals (Patterson \& Padgett 2000, Shi \& Massagué 2003). Hence, in normal cells, TGF $\beta$ acts as a tumor suppressor by inhibiting cell growth or by promoting cellular differentiation or apoptosis.

At some time during the stepwise transition towards malignancy, human cancer cells acquire several abilities that most normal cells do not have, including the ability to become, at least partially, resistant to growth inhibition, to proliferate without dependence on growth factors, to replicate without limit, to invade, and to metastasize. TGF $\beta$ is one of the complex signal transduction pathways that control normal cellular homeostasis regulating these processes. TGF $\beta$ signaling is propagated via cell surface Ser/Thr kinases, TGF $\beta$ type I receptor (T $\beta R I$, listed in the HGNC database as TGFBR1), and TGF $\beta$ type II receptor (T $\beta$ RII, TGFBR2), followed by an intracellular cascade of events involving receptor-regulated SMADs (R-SMADs), SMAD2 and
SMAD3, and their interacting partner, commonmediator SMAD, SMAD4. Once formed the complexes, the SMADs translocate in the nucleus where they regulate target genes (Attisano \& Wrana 2000). In contrast, the inhibitory SMAD (I-SMAD), SMAD7, binds to T $\beta R I$ and prevents the phosphorylation of R-SMADs, resulting in the inhibition of TGF $\beta$ signaling (Imamura et al. 1997, Nakao et al. 1997). A SMAD ubiquitin regulatory factor 1 (SMURF1), being a HECTtype E3 ubiquitin ligase, interacts with I-SMAD7 and enhances the turnover of T $\beta$ RI (Suzuki et al. 2002). TGF $\beta$ elicits context-dependent and cell-specific effects that often appear conflicting. It is puzzling how a seemingly direct transduction scheme, dependent on shuttling of SMAD proteins from the cytoplasm to the nucleus, can mediate such diverse array of responses.

TGF $\beta$ is normally expressed and secreted in epithelial follicular thyroid cells. In thyroid cell lines, the differentiated phenotype is controlled by TGF $\beta$, which inhibits iodide trapping (Taton et al. 1993, Pekary \& Hershman 1998) and thyroglobulin synthesis (Colletta et al. 1989); some of these effects are exerted through SMAD signaling (Nicolussi et al. 2003, Costamagna et al. 2004). TGF $\beta$ is also the negative regulator of thyrocyte proliferation: it antagonizes the mitogenic effects of the main growth factors in thyroid cells of rat (Morris et al. 1988, Colletta et al. 1989, Coppa et al. 1995, Carneiro 
et al. 1998), of porcine (Franzén et al. 1999), and of humans (Wyllie et al. 1991), and delays progression during the mid-late $\mathrm{G}_{1}$ phase (Carneiro et al. 1998, Depoortere et al. 2000).

Several studies on surgical samples and on thyroid cell cultures have been performed showing the role of TGF $\beta$ and other members of TGF $\beta$ superfamily in thyroid proliferative diseases: benign cases (Morosini et al. 1994) and malignant ones (Heldin et al. 1999, Kimura et al. 1999, Cerutti et al. 2003). These data support the hypothesis that this growth factor is important in thyroid cell physiology, modulating thyroid functions and proliferation, and justify the need to study also the proteins involved in signaling from the cytoplasm to the nucleus.

The objective of this study was to determine the functional role of TGF $\beta$ pathway in human papillary thyroid carcinogenesis. For this purpose, we examined the TGF $\beta$ response in two cell lines, TPC- 1 and BCPAP, and in a group of 23 cases of human papillary thyroid carcinomas (PTCs). Our data demonstrated for the first time that these cells showed a strong reduction in the level of SMAD4 protein, which was responsible for an alteration of TGF $\beta$ signaling and for some of the TGF $\beta$ mediated biological effects. The overexpression of SMAD4, restoring TGF $\beta$ transduction, determined a significant increase of antiproliferative response to TGF $\beta$, and reduced the invasive behavior of these cells. Therefore, these data indicate that reduction of SMAD4 may play a significant role in thyroid carcinogenesis.

\section{Materials and methods}

\section{Reagents and constructs}

DMEM, Coon's modified Ham's F-12 medium, PBS, FBS, trypsin-EDTA, L-glutamine $100 \times(200 \mathrm{mM})$, and the six-hormone mixture $(6 \mathrm{H})$ containing TSH $(10 \mathrm{mU} / \mathrm{ml})$, insulin $(10 \mu \mathrm{g} / \mathrm{ml})$, hydrocortisone $\left(10^{-8} \mathrm{M}\right)$, transferrin $(5 \mu \mathrm{g} / \mathrm{ml})$, glycyl-L-histidyl-L-lysine acetate $(10 \mathrm{ng} / \mathrm{ml})$, and somatostatin $(10 \mu \mathrm{g} / \mathrm{ml})$ were purchased from Sigma-Aldrich, Co.

The human recombinant TGF $\beta 1$ isoform was purchased by Peprotech (Rocky Hill, NJ, USA). MG132 was provided by Calbiochem (La Jolla, CA, USA).

Phenylmethylsulfonyl fluoride (PMSF), protease inhibitor cocktail containing $1 \mathrm{mg} / \mathrm{ml}$ leupeptin, $2.5 \mathrm{mg} / \mathrm{ml}$ aprotinin, and $1 \mathrm{mg} / \mathrm{ml}$ benzamide hydrochloride, and phosphatase inhibitor cocktail were purchased from Sigma-Aldrich, Co. Antibodies to T $\beta R I$ and T $\beta$ RII, green fluorescent protein (GFP), SMURF1 (H60), SMAD7 (H79), SMAD4 (B8), SMAD4 (H552), $\mathrm{N}$-cadherin (H63), $\beta$-actin (C4), and Lamin B (C20) were obtained from Santa Cruz Biotechnology (Santa Cruz,
CA, USA). Antibodies to the phosphorylated form of SMAD2 (SMAD2-P) and SMAD3 (SMAD3-P) were obtained from Cell Signaling Technology (Beverly, MA, USA), to SMAD2-P from Millipore (Billerica, MA, USA), to E-cadherin from Immunological Sciences (Rome, Italy), to SMAD3 from Zymed Laboratories (San Francisco, CA, USA), and to SMAD2/ SMAD3 from BD Biosciences PharMingen (San Diego, CA, USA). Texas Red-conjugated goat anti-mouse IgG was obtained from Jackson Laboratories (Bar Harbor, ME, USA); FITCconjugated goat anti-mouse and goat anti-rabbit IgG was obtained from Cappel (Organon Teknica Corp., West Chester, PA, USA).

Transfections were performed using lipofectin kit provided by LipofectAMINE PLUS (Gibco BRL, Life Technologies).

GFP-tagged SMAD4 wt was constructed subcloning the human SMAD4 gene in CLONTECH pEGFPC3 vector, which allows in-frame fusion to the $\mathrm{C}$ terminus of GFP. pCMV5 3TP-Lux, pCMV5- $\beta \mathrm{Gal}$, and pCMV5 FLAG-SMAD2 wt have been gently provided by Prof. Liliana Attisano.

\section{Cell cultures and transient transfection analysis}

TPC-1 and BCPAP (human PTC cell lines), and FRO (human anaplastic thyroid carcinoma cell lines) were kindly provided by Prof. Alfredo Fusco and were maintained in culture as previously described (Iuliano et al. 2003). The FRTL-5 cells were kindly provided by Dr L D Kohn. This cell line, diploid between their 5th and 25th passage, maintains the functional characteristics of iodide uptake, thyroglobulin synthesis, and cyclic nucleotide metabolism over prolonged periods of culture and doubling time of $\sim 36 \mathrm{~h}$ (AmbesiImpiombato et al. 1980). These cells were grown as previously described (Nicolussi et al. 2003) at $37^{\circ} \mathrm{C}$ in a humidified atmosphere of $5 \% \quad \mathrm{CO}_{2}$ air in w/o supplemented with $5 \%$ calf serum and $6 \mathrm{H}$ mixture. FTC133, human follicular thyroid tumor cell line (Goretzki et al. 1990), kindly provided by Prof. Salvatore Ulisse, MCF7 and MDA MB468 (Schutte et al. 1996), breast cancer cell lines, HepG2, human hepatoma cell line, and HEK293, derived from human embryonic kidney cells, purchased from American Type-Culture Collection (ATCC, Rockville, MD, USA), were grown at $37^{\circ} \mathrm{C}$ in a humidified atmosphere of $5 \% \mathrm{CO}_{2}$ air in DMEM supplemented with $10 \%$ calf serum.

TPC-1 and BCPAP were transiently cotransfected with empty vectors or pEGFPC3-SMAD4 wt and/or pCMV5 FLAG-SMAD2 wt using lipofectin technique following the manufacturer's instructions. After $24 \mathrm{~h}$ of incubation, transfected cells were used in immunofluorescences, luciferase assays, proliferation assays, wound-healing assays, and western blot assays. 


\section{Proliferation assays}

The cell proliferation was assessed by cell counting. Briefly, $5 \times 10^{4}$ cells were seeded into $35 \mathrm{~mm}$ plates and allowed overnight at $37^{\circ} \mathrm{C}$ in a humidified incubator with $5 \% \mathrm{CO}_{2}$. Cell numbers were determined using a hemacytometer both at time zero (T0), to determine the number of cells in the plates before the TGF $\beta 1$ treatment, and after 24 and $48 \mathrm{~h}$ with or without $10 \mathrm{ng} / \mathrm{ml}$ of TGF $\beta 1$ in serum-free medium. Cells were counted three times by two independent investigators. Inter-observer variation was below $5 \%$. Values represent the mean of triplicate determination \pm s.D. of three experiments, and the results were also presented as a percentage of growth inhibition with respect to relative untreated control for each time point.

\section{Luciferase assays}

These assays were carried out as described previously (Nicolussi et al. 2003, 2006). After transfection, cells were treated or untreated with $10 \mathrm{ng} / \mathrm{ml}$ of TGF $\beta 1$ in serum-free medium. Luciferase activities were normalized for transfection efficiency using the $\beta$-galactosidase-expressing control vector. The experiments were repeated four times in triplicate.

\section{Protein extraction and western blotting analysis}

Protein extracts were obtained as previously described (Nicolussi et al. 2006). Subconfluent cells, transfected or not, were treated or untreated with $10 \mathrm{ng} / \mathrm{ml}$ of TGF $\beta 1$ for 30,60 , or $120 \mathrm{~min}$ or with MG132 $(30 \mu \mathrm{M})$ for $24 \mathrm{~h}$.

To obtain the cytosolic and nuclear fractions, cells were lysed in $0.4 \mathrm{ml}$ hypotonic buffer A ( $10 \mathrm{mM}$ Hepes,

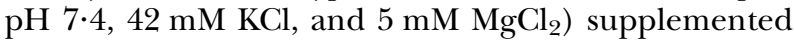
with protease inhibitor cocktail. After centrifugation of lysate at $1200 \mathrm{~g}$ for $10 \mathrm{~min}$, the supernatant containing the cytosolic fraction was clarified by centrifugation at $15000 \mathrm{~g}$ for $1 \mathrm{~h}$ at $4^{\circ} \mathrm{C}$. The pellet containing nuclear fraction was repeatedly washed in a specific buffer $\mathrm{B}$ (10 mM Hepes, pH 7.4, $10 \mathrm{mM} \mathrm{KCl,} 1.5 \mathrm{mM} \mathrm{MgCl}_{2}$, and $0.1 \mathrm{mM}$ EDTA) and resuspended in extraction buffer C (20 mM Hepes, pH 7•4, 25\% glycerol, $0 \cdot 4 \mathrm{M}$ $\mathrm{NaCl}, 1.5 \mathrm{mM} \mathrm{MgCl}_{2}$, and $0.2 \mathrm{mM}$ EDTA), supplemented with protease inhibitor cocktail, PMSF, and dithiothreitol. Protein extracts were subjected to immunoblotting as previously described (Nicolussi

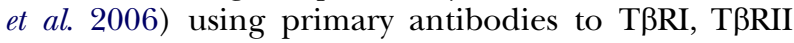
(1:600), SMAD2-P (1:1000), SMAD3-P (1:1000), SMAD3 $(1: 1000)$, GFP (1:500), E-cadherin (1:1000), N-cadherin (1:500), Lamin B (1:1000), SMAD2/ SMAD3 (1:500), SMAD4 (1:500), and $\beta$-actin (1:5000). SMAD4, E-cadherin, SMAD2-P, and SMAD3-P bands were analyzed using Bio-Rad Laboratories software. Data, obtained from three different protein extracts, were collected in terms of average intensity of bands of each proteins per average intensity of bands of $\beta$-actin or SMAD2.

\section{RNA isolation and analysis}

RNA was extracted using Tri Reagent (Sigma-Aldrich, Co.), following the manufacturer's instructions. Using $1 \mu \mathrm{g}$ RNA, cDNAs were synthesized using MuLV reverse transcriptase (Applied Biosystems, Hammonton, NJ, USA) and random primers (Roche) according to the manufacturer's instructions. The primers used in the amplification of human SMAD4 (SMAD4-A forward 5'-CCTTGCAACGTTAGCTGTTG-3', reverse 5'-CTTCAGTGGACAACGATG-3'; SMAD4-B forward 5'-CACTGCAGAGTAATGCTCC-3' ${ }^{\prime}$, reverse 5'-GTCCACGTATCCATCAAC-3'; $S M A D 4-\mathrm{C}$ forward $5^{\prime}$-GATGTTCAGGTAGGAGAG-3', reverse 5'-CCAACGGTAAAAGACCTCAG$\left.3^{\prime}\right)$ and $G A P D H$ genes as internal control (GAPDH forward 5'-ACCACAGTCCATGCCATCAC-3' ${ }^{\prime}$, reverse GAPDH $\quad 5^{\prime}$-TCCACCACCCTGTTGCTGTA-3') were designed to cross intron-exon junctions. The amplified cDNAs were purified with a gel cleanup kit, and subjected to sequencing reactions (MWG Biotech AG, Martinsried, Germany). All the obtained sequences corresponded to the expected ones (data not shown).

Real-time reverse transcription (RT)-PCR was performed three times in six replicates on a 7500 RT-PCR System (Applied Biosystems) using the SYBR Green detection system. mRNA levels were compared with reference curves and normalized to GAPDH mRNA. Each experiment was repeated three times using different total RNA extracts.

\section{Immunofluorescence experiments}

Immunofluorescences were carried out as described previously (Nicolussi et al. 2006). Cells were incubated with or without $10 \mathrm{ng} / \mathrm{ml}$ of TGF $\beta 1$ in serum-free medium for $1 \mathrm{~h}$ and then fixed with $4 \%$ paraformaldehyde/PBS for $30 \mathrm{~min}$, followed by treatment with $0 \cdot 1 \mathrm{M}$ glycine/PBS for $20 \mathrm{~min}$ and permeabilized with $0 \cdot 1 \%$ Triton X-100 for additional $5 \mathrm{~min}$. For detection of SMAD2/SMAD3 and SMAD2-P, cells were incubated with anti-SMAD2/3 antibody $(1: 50)$ and SMAD2-P antibody (1:50) for $1 \mathrm{~h}$ respectively, followed by Texas Red-conjugated goat anti-mouse IgG (1:50). For detection of SMAD4, cells were incubated with anti-SMAD4 antibody (1:100), followed by FITCconjugated goat anti-mouse IgG $(1: 10)$. Nuclei were stained with $10 \mu \mathrm{g} / \mathrm{ml} 4^{\prime}, 6^{\prime}$-diamidino-2-phenylindole (Sigma-Aldrich, Co.). 
Immunofluorescences in cells transiently transfected with pEGFPC3-SMAD4 wt or pEGFPC3 empty vector were carried out as described above. The anti-GFP antibody (1:100) was used to detect GFP-tagged SMAD4 protein. Fluorescence was observed with an Olympus BX51 microscope and photographed at $40 \times$ optical magnification. Each experiment was repeated three times.

\section{Wound-healing assay}

TPC-1, BCPAP, and FRTL-5 cells, native or transiently transfected, were plated in $35 \mathrm{~mm}$ dish and cultured to confluence of $90 \%$. Cell layers were then scratched with a pipette tip, and cellular debris has been removed washing gently. Some plates were fixed and photographed immediately after scratching (T0 control). The cells that were allowed to incubate with serum-free medium for $24 \mathrm{~h}$ were fixed with $4 \%$ paraformaldehyde for $30 \mathrm{~min}$, and dishes were plated under a phase contrast microscope Axio Observer (Carl Zeiss, Inc., Oberkochen, Germany) and photographed to measure the gap distance using the computing software Axio Vision (Carl Zeiss, Inc.). Each result is the mean of three independent experiments.

\section{Tissue samples and immunohistochemistry analysis}

A group of 23 PTCs, collected at the Anatomic Pathology of Department of Experimental Medicine of Sapienza University of Rome from 2008 to 2010, were used. Thyroid tissue sections were studied using the catalyzed signal amplification protocol (DAKO A/S, Glostrup, Denmark; Lazzereschi et al. 1997). Slides were incubated in a humidified chamber overnight at $41^{\circ} \mathrm{C}$ with 1:100 dilution of polyclonal serum to SMAD4 (H552). The peroxidase-based LSAB2 Detection kit (DAKO A/S), followed by hematoxylin counterstaining, was used to visualize the reactions. Written informed consent was obtained from each patient according to Helsinki Declaration and approved by the local ethics committee.

\section{Statistical analysis}

All statistical analyses have been performed using JMP Software purchased by Statistical Discovery SAS Institute (Cary, NJ, USA). Data were analyzed by the following tests: Student's $t$-test; Fisher test across groups ( $P$ value referred to $F$ value); non-parametric one-way ANOVA Wilcoxon/Kruskal-Wallis test $(P$ value referred to $\chi^{2}$-value). $P<0 \cdot 05$, statistical significance; $P<0 \cdot 001$, high statistical significance.

\section{Results}

\section{TGF $\beta$ signaling in TPC-1 and BCPAP}

Expression of members of TGF $\beta$ pathway has been studied in TPC-1 and BCPAP cells. These cells represent a model of human papillary thyroid cell lines, whose thyroid origin has been confirmed by RT-PCR for the presence of RET/PTC rearrangement and $P A X 8$ expression in TPC-1 and PAX 8 and TTF1 expression in BCPAP (data not shown).

The control cells used in this study were a human follicular cell line, FTC133, and a normal rat thyroid cell line, FRTL-5. FTC133 retains the differentiated thyrocyte functions like responsiveness to TSH for the presence of TSH receptor, TTF1, and PAX8 confirmed by RT-PCR; FRTL-5 was widely used as a normal control (Pang et al. 1989, Shimura et al. 2001, Pomérance et al. 2006, Visconti et al. 2007, Kogai et al. 2008).

Western blot analyses performed on total cell lysates, using polyclonal antibodies anti-T $\beta$ RII and anti-T $\beta$ RI, demonstrated that both receptors were present in all examined cell lines (Fig. 1A), and they were not modified by TGFB $\beta 1$ treatment (data not shown). Since the expression of T $\beta R I$ was lower in TPC-1 and in BCPAP with respect to the control cells, we assayed the level of SMAD7 and SMURF1 to assess whether there was an alteration in the mechanism of T $\beta R I$ degradation. The expression of these proteins was comparable in all cell lines (Fig. 1A). Consistent with the finding that the expression of SMAD7 is induced by TGF $\beta$, the level of this protein was increased by TGF $\beta 1$ treatment, demonstrating that this branch of signaling was functioning in PTC cell lines (data not shown). As an indication of the ability of the lower level of T $\beta$ RI to phosphorylate SMAD2 and SMAD3, we performed western blot analyses with or without $10 \mathrm{ng} / \mathrm{ml}$ of TGF $\beta 1$ treatment for $30 \mathrm{~min}$. Our data demonstrated that SMAD2 and SMAD3 were phosphorylated both in TPC-1 and in BCPAP, as in FTC133 and FRTL-5 control cells (Fig. 1B and C).

The transcriptional activity of the TGF $\beta$ cascade was evaluated using a TGF $\beta$-responsive reporter construct, p3TP-Lux. The p3TP promoter contains three consecutive 12-O-tetradecanoyl phorbol 13-acetate (TPA) response elements, which are involved in the transcriptional responses of several genes to TGF $\beta$, and a portion of the plasminogen activator inhibitor-1 promoter region (de Groot \& Kruijer 1990, Keeton et al. 1991, Wrana et al. 1992). The results showed (Fig. 1D) that the increase of transcriptional activity, after $24 \mathrm{~h}$ of TGF $\beta 1$ treatment, was not significant both in TPC-1 $(3 \cdot 5$-fold) and in BCPAP (3.1-fold), while it was significant both in FTC133 $(10 \cdot 3$-fold, $P<0 \cdot 001)$ and in FRTL-5 (25-fold, $P<0 \cdot 001$ ). 
Altogether, our data demonstrated an important impairment of TGF $\beta$ signaling in papillary thyroid cell lines.

\section{SMAD4 expression in TPC-1 and BCPAP}

Based on the observation of frequent inactivation of SMAD4 in several types of tumors, we analyzed SMAD4 expression in TPC-1, BCPAP, and in a set of different human cell lines: MDA MB468, FRO, and humanimmortalized B lymphocytes. FTC133 and FRTL-5 were used as a positive control, whereas MDA MB468, in which SMAD4 was deleted in homozygosis, was used as a negative control. Western blot in Fig. 2A shows that SMAD4 expression was strongly reduced in all PTC cells with respect to FTC133 and FRTL-5. Densitometric analysis of bands confirmed a significant $(P<0.05)$ reduction with respect to FTC133 both in TPC-1 $(66 \%)$ and in BCPAP (72\%), and with respect to FRTL-5 both in TPC-1 $(69 \%)$ and in BCPAP $(75 \%)$.

The expression of SMAD4 gene was studied by RT-PCR. As shown in Fig. 2B, all the primers, used for RT-PCR, amplified fragments of the expected size both in PTC cells and in human controls (FTC133, FRO, human-immortalized B lymphocytes, and MCF7). Since mutational inactivation of SMAD4 in different carcinomas has been reported, we sequenced the CDS region of SMAD4 cDNA to look for nucleotide alterations. Nucleotide sequencing did not show any changes in all examined cell lines (data not shown).

SMAD4 mRNA levels were evaluated by semiquantitative real-time PCR on CDNA of TPC-1 and BCPAP and a set of positive controls (FTC133, HepG2, and HepG2 transfected with pEGFPC3-SMAD4 wt) and a negative control (MDA MB468). The results obtained demonstrated that all cell lines showed a comparable level of SMAD4 transcript (Fig. 2C). Therefore, these data suggested that the cause of hypoexpression of SMAD4 protein in these cells could be an alteration in one of the post-transcriptional mechanisms.

To analyze the implications of proteasome in SMAD4 degradation, we treated cell lines for $24 \mathrm{~h}$ with MG132, an inhibitor of proteasome activity. As showed in Fig. 2D, MG132 treatment determined an increase of SMAD4 level in both cell lines, likewise in FRTL-5 and FTC133 (about $1 \cdot 5$-fold). These results indicated that the ability of proteasome to degrade SMAD4 in these cells was preserved, but not enhanced.

\section{Shuttling of SMAD proteins}

The molecular mechanism that controls subcellular localization and activation of SMAD proteins is crucial for transduction of TGF $\beta$ signal from transmembrane receptors into the nucleus, and it is not yet fully understood. The immunofluorescence experiments
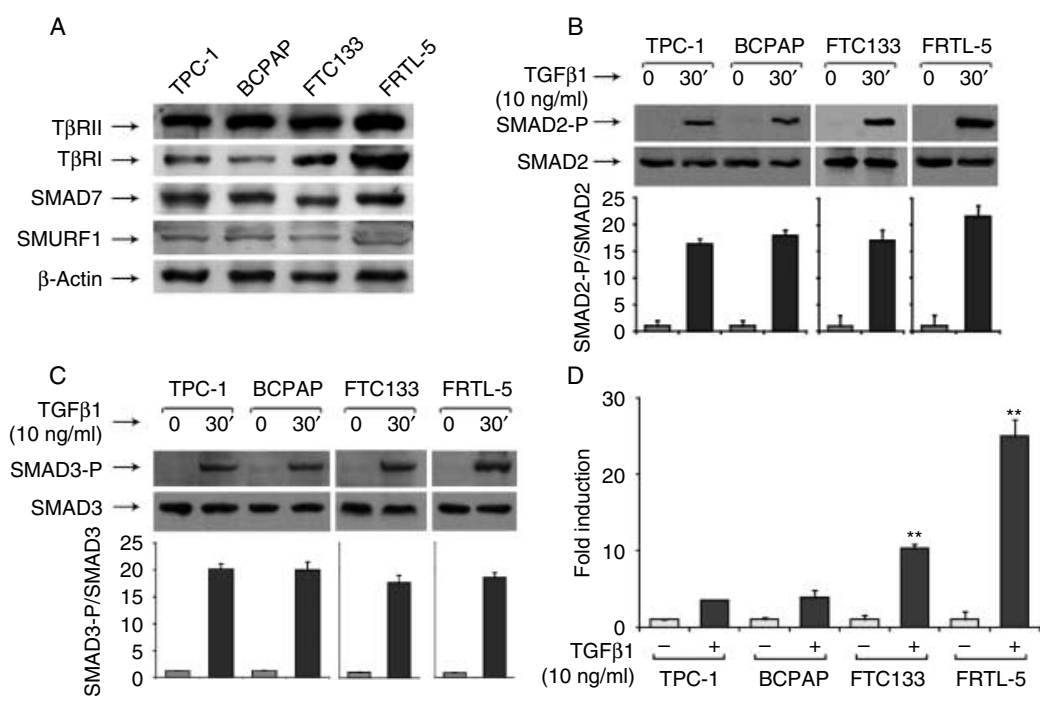

Figure 1 TGF $\beta$ signaling in TPC-1 and BCPAP. (A) Whole cell extracts ( $40 \mu \mathrm{g} / \mathrm{lane}$ ) were analyzed by western blot, using antibodies against T $\beta$ RII, T $\beta R I$, SMAD7, SMURF1, and $\beta$-actin as equal loading control. (B and $C$ ) Phosphorylation of SMAD2 and SMAD3 after treatment with $10 \mathrm{ng} / \mathrm{ml}$ of TGF $\beta 1$ for $30 \mathrm{~min}$. Histograms of densitometric analysis of the SMAD2-P and SMAD3-P bands normalized to the respective unphosphorylated forms. (D) Cells were transiently transfected with 3TP-Lux reporter and grown for $24 \mathrm{~h}$ in the presence or the absence of $10 \mathrm{ng} / \mathrm{ml}$ of TGF $\beta 1$. Luciferase activity was expressed in fold induction \pm s.D. Each result is the mean of four independent experiments ${ }^{* *}$ indicates a high statistical significance (Student's $t$-test, $P<0.001$ ) correlate to untreated cells). 
A

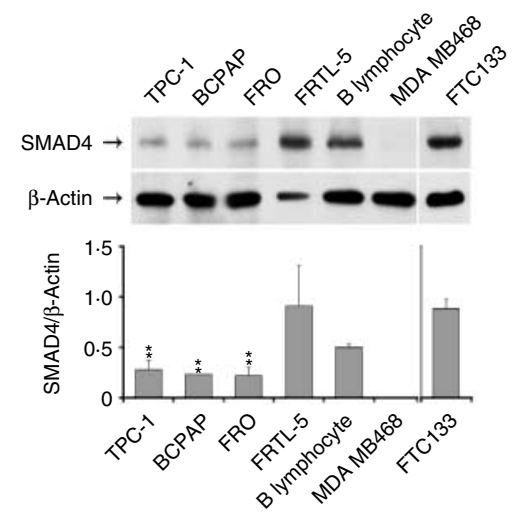

C

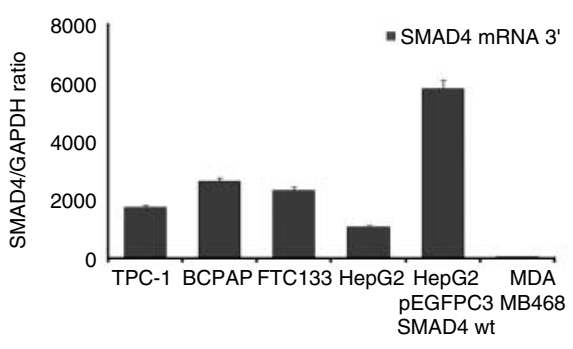

B

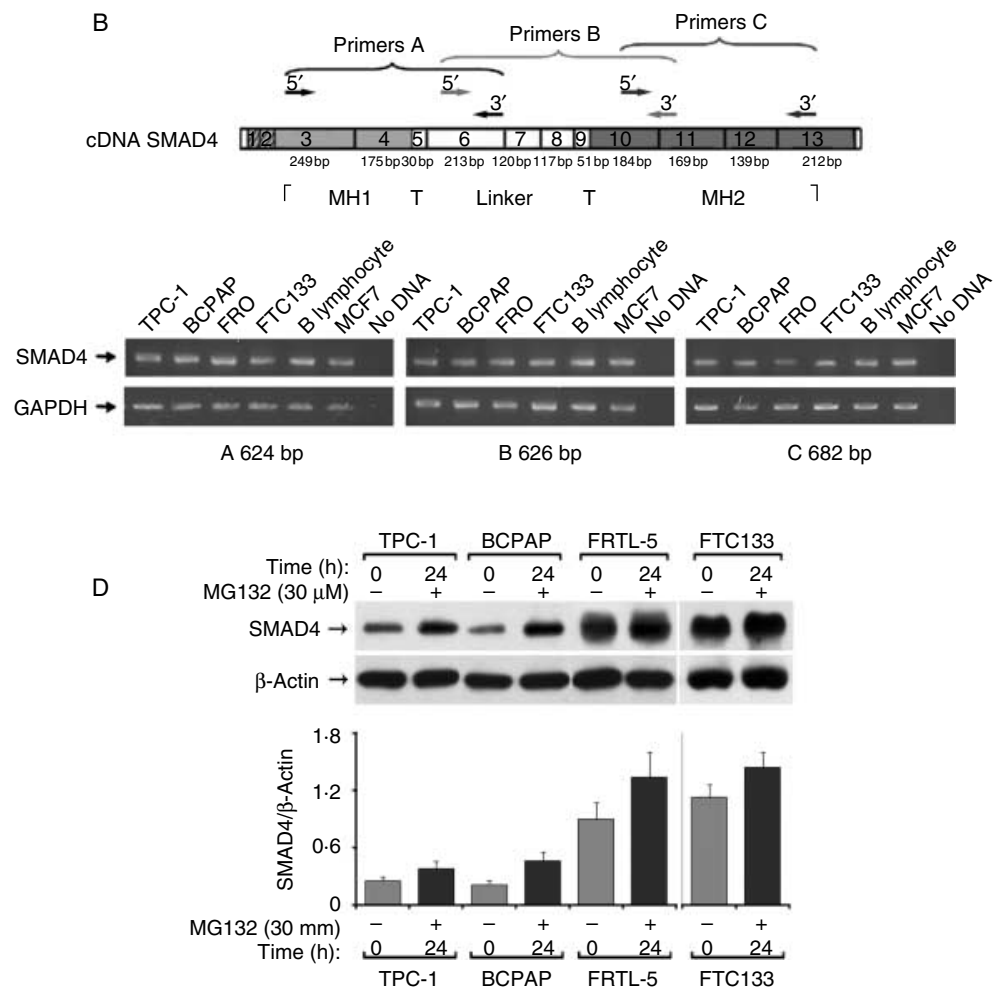

Figure 2 Expression of SMAD4. (A) Whole protein lysates (80 $\mu \mathrm{g} / \mathrm{lane})$ from TPC-1, BCPAP, FTC133, FRTL-5, and a set of different human cell lines MDA MB468, FRO, and human-immortalized B lymphocytes were analyzed by western blot using an antibody against SMAD4. Densitometric evaluation of the SMAD4 signals was performed normalizing to the levels of $\beta$-actin (* indicates a statistical significance (Student's $t$-test, $P<0.05$ ) correlate to FTC133 and FRTL-5). (B) The upper part of panel shows a schematic representation of specific primers for SMAD4 used for the amplification. GAPDH was used as a housekeeping gene.

(C) Semiquantitative real-time PCR analysis of SMAD4 mRNA levels. Data reported represent the mean of three independent experiments. FTC133, HepG2, and HepG2 transiently transfected with pEGFPC3-SMAD4 wt construct and MDA MB468 samples were used as controls in the experiments. (D) Total protein lysates $(80 \mu \mathrm{g} / \mathrm{lane})$ from TPC-1, BCPAP, FTC133, and FRTL-5, treated or untreated with MG132 $(30 \mu \mathrm{M})$ for $24 \mathrm{~h}$, were analyzed by western blot using an anti-SMAD4 antibody. Histogram of densitometric analysis of SMAD4 levels normalized to the levels of $\beta$-actin.

demonstrated that in unstimulated cells, SMAD2 was predominantly cytoplasmic, whereas after $1 \mathrm{~h}$ of TGF $\beta 1$ treatment, it was localized throughout the cytoplasm and the nucleus, as a result of its shuttling between these two compartments (Fig. 3A). The localization of SMAD2-P, clearly cytoplasmic in basal condition, became nuclear after TGF $\beta 1$ treatment in all cell lines (Fig. 3A).

The nuclear translocation of SMAD4 was investigated in the same cells and in the negative control represented by MDA MB468. SMAD4 not only accumulates in the nucleus in association with activated R-SMADs, but also undergoes continuous nucleocytoplasmic shuttling on its own, independently of TGF $\beta$ signaling (Pierreux et al. 2000, Watanabe et al. 2000). In accordance with these findings, the data presented in Fig. 3B demonstrated the presence of continuous nucleocytoplasmic shuttling both in basal condition and after TGF $\beta 1$ treatment. Therefore, the SMAD4 ability to translocate to the nucleus was preserved, and the weak cellular fluorescence signal observed in TPC-1 and in BCPAP was due to the hypoexpression of this protein.

Western blot performed on the cytoplasmic and nuclear extracts of TPC-1, BCPAP, and FRTL-5 demonstrated a clear nuclear translocation of SMAD4 and SMAD2-P, after 30 and 60 min of TGF $\beta 1$ treatment in all cell lines. The presence of SMAD2 and SMAD4 in the cytoplasmic fractions in all cell lines, after TGF $\beta 1$ treatment, confirmed the continuous nucleocytoplasmic shuttling of these proteins (Fig. 4).

\section{SMAD4 overexpression in TPC-1 and BCPAP}

In order to study the effects of the SMAD4 overexpression, the cells have been transiently transfected with a construct containing human SMAD4 wt, tagged with GFP (pEGFPC3-SMAD4), or with a construct containing human SMAD2 wt tagged with FLAG (pCMV5 FLAG-SMAD2) or cotransfected with both 

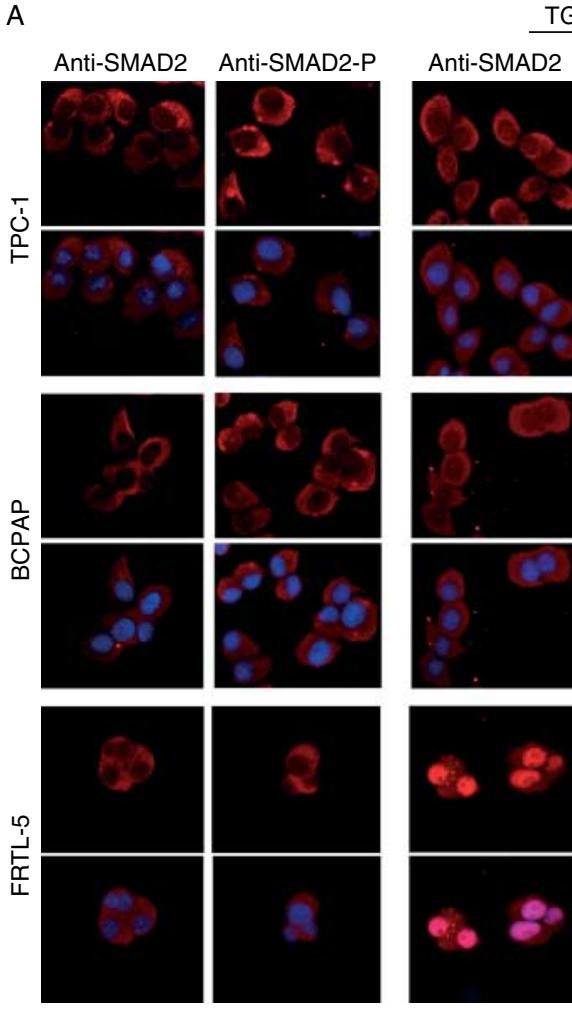

TGF $\beta 1$
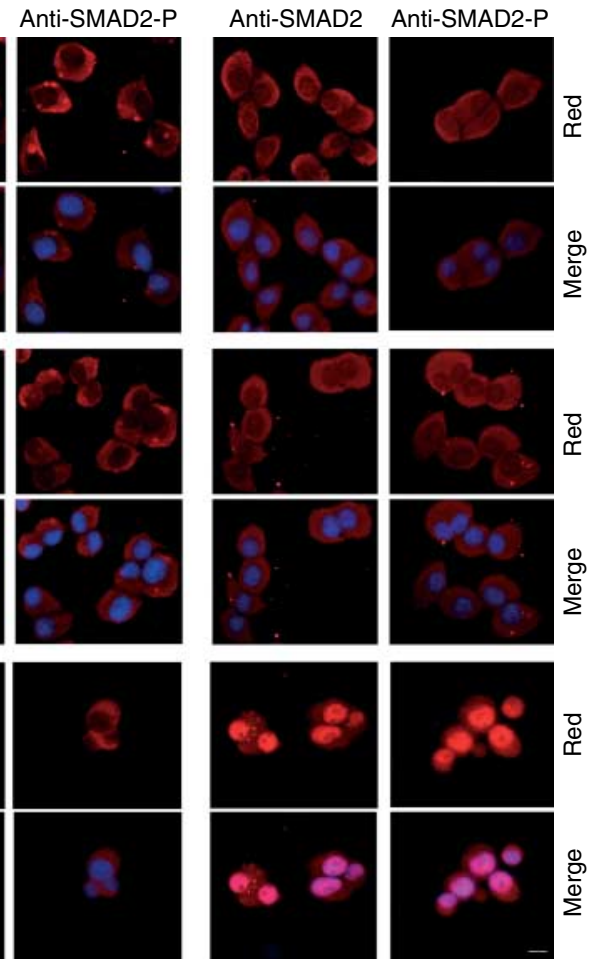

B
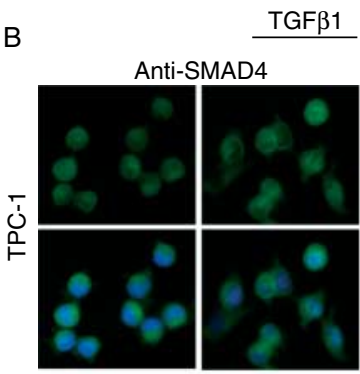

Anti-SMAD4
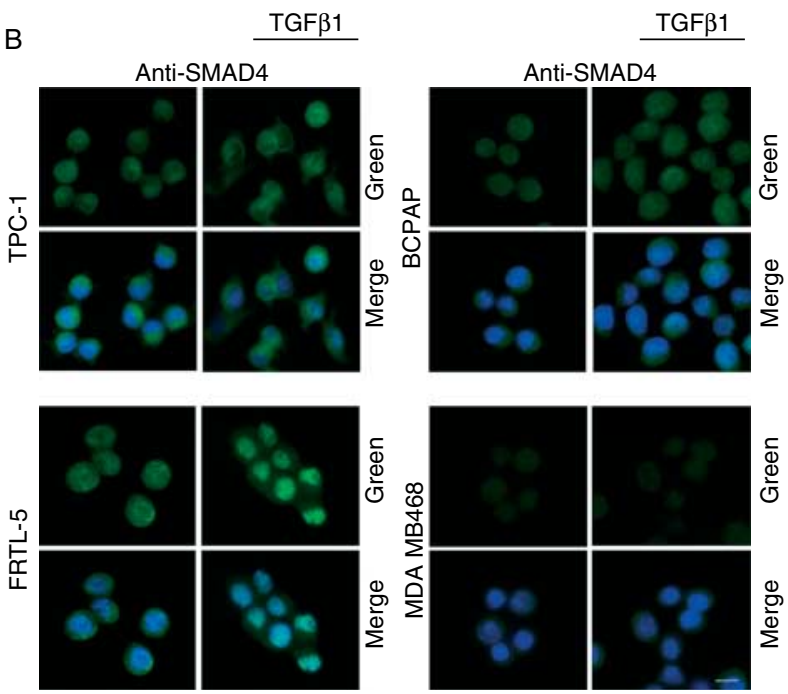

Figure 3 Subcellular localization of SMAD2 and SMAD4. (A and B) TPC-1, BCPAP, and FRTL-5, treated or untreated with $10 \mathrm{ng} / \mathrm{ml}$ of TGF $\beta 1$ for $1 \mathrm{~h}$, were fixed and immunolabeled for SMAD2, SMAD2-P, and SMAD4. Nuclei were counterstained with DAPI. Images are representative of three separate experiments. Scale bar, $20 \mu \mathrm{m}$.

plasmids. The transcriptional activity of $S M A D 4$ was studied using the p3TP-Lux reporter construct in the presence or in the absence of $10 \mathrm{ng} / \mathrm{ml}$ of TGF $\beta 1$ for $24 \mathrm{~h}$. The results, evaluated by Student's $t$-test, demonstrated a significant $(P<0.05)$ increase of 3TP-Lux activity in TPC-1 transfected with SMAD4 or SMAD4-SMAD2-cotransfected cells versus cells transfected with reporter construct. In BCPAP, the increase was highly significant $(P<0 \cdot 001)$ in SMAD4-transfected cells versus cells transfected with reporter construct, and the increase was significant $(P<0.05)$ in SMAD4/SMAD2-cotransfected cells versus cells transfected with reporter construct (Fig. 5A).

The response to TGF $\beta 1$ treatment between each group and across groups was evaluated by matched pair test. The Student's $t$-test between groups demonstrated that the transcriptional activity was significantly increased $(P<0 \cdot 001)$ in all conditions examined (Fig. 5A). Fisher test across groups $(P$ value referred to $F$ value) demonstrated that the luciferase induction after TGF $\beta 1$ treatment was statistically significant in all of the following conditions: TPC-1 cells transfected with $S M A D 4$ versus cells transfected with reporter construct $(P=0.0204)$ or versus cells transfected with $S M A D 2$ $(P=0 \cdot 0034)$ and $S M A D 4-/ S M A D 2$-cotransfected cells versus cells transfected with reporter construct $(P=0 \cdot 0144)$; BCPAP cells transfected with SMAD4 versus cells transfected with reporter construct $(P=0 \cdot 0010)$ or versus cells transfected with SMAD2 $(P=0 \cdot 0015)$. The results obtained in SMAD4-/SMAD2cotransfected cells versus cells transfected with reporter demonstrated an increase of luciferase activity $(P=0.0516$; Fig. 5A). The Fisher test across groups in a matched pair test evaluates the difference in the response to TGF $\beta 1$, but does not take into account the baseline values induced by the overexpression of $S M A D 4$. To determine whether the fold induction in 3TP-Lux reporter activity for TPC-1 and BCPAP was significantly increased by $S M A D 4$ overexpression, we examined the data using the non-parametric one-way ANOVA Wilcoxon/Kruskal-Wallis test ( $P$ value referred to $\chi^{2}$-value). The results obtained demonstrated that the mean of fold induction of transcriptional activity, after TGF $\beta 1$ treatment in non-transfected TPC-1, was 3.6 vs $4.2(P<0.0076)$ in $S M A D 4$-transfected cells, and the mean of fold induction in non-transfected BCPAP was $3 \cdot 1$ vs $4 \cdot 1 \quad(P<0 \cdot 0466)$ in $S M A D 4$-transfected cells (Fig. 5A). These results showed that in transfected cells, the fold induction of luciferase activity was significantly increased after TGF $\beta 1$ treatment: the level of SMAD4 in the cells was causing this response.

To verify whether the reduction of SMAD4 shuttling was caused by hypoexpression of this protein, we performed immunofluorescences in transfected cells, using an antibody specific for GFP. The results shown in Fig. 5B demonstrated that the overexpression of SMAD4 determined a very strong nuclear translocation of SMAD4 after TGF $\beta 1$ treatment (upper panel), with respect to the control cells transfected with empty vector (lower panel). Western blot confirmed the 

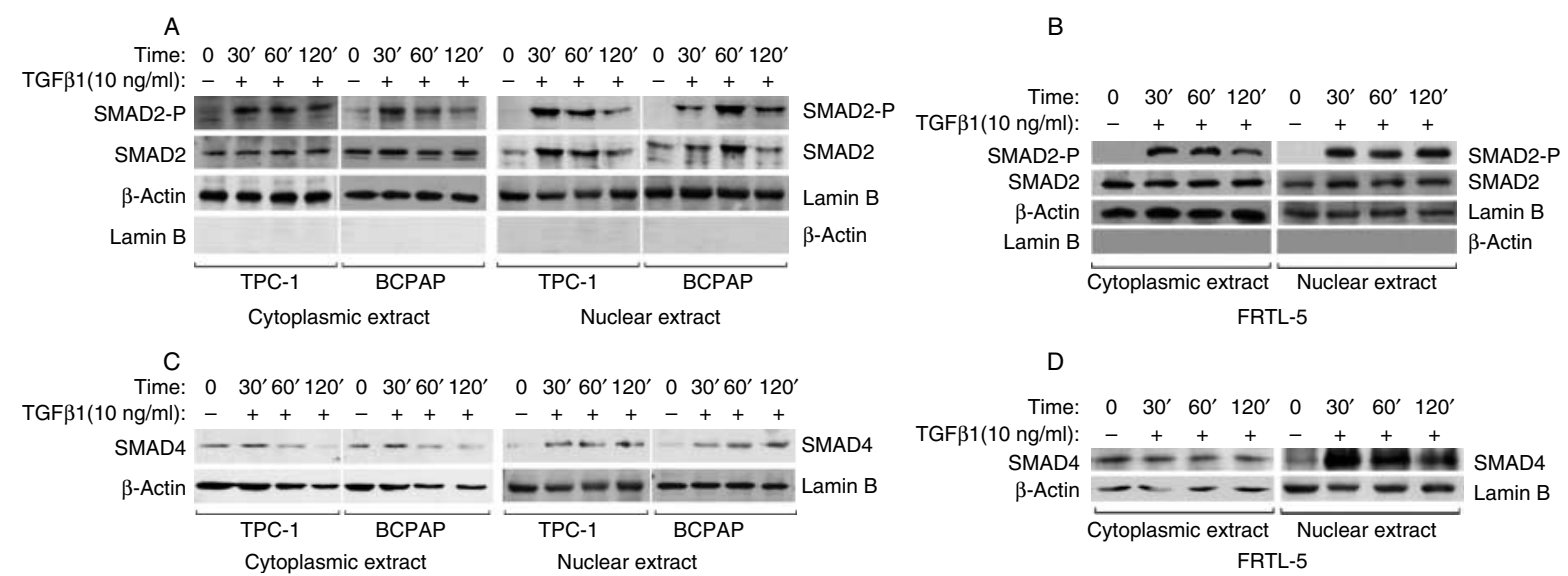

Figure 4 Subcellular fractionation of SMAD2, SMAD2-P, and SMAD4. (A-D) Cells, treated with $10 \mathrm{ng} / \mathrm{ml}$ of TGF $\beta 1$ for indicated time periods, were separated into cytosol and nuclear fractions before analyss by immunoblotting with the SMAD2, SMAD2-P $(A$ and $B)$, and SMAD4 (C and $D)$ antibodies. Western blots, performed using antibodies against the $\beta$-actin, cytoplasmic protein, and against Lamin $B$, nuclear protein, indicated that the extracts are virtually free from cross-contamination.

overexpression of GFP-tagged SMAD4 protein in transiently transfected cells (Fig. 5C).

Taken together, these data indicated that the attenuated signaling pathway observed in TPC-1 and BCPAP could result from the low levels of SMAD4, and the hyperexpression of this protein was responsible for a significant enhancement of TGF $\beta$ responsiveness.

\section{TGF $\beta$ growth inhibition in TPC-1 and BCPAP}

The responsiveness to TGF $\beta$ growth inhibition has been evaluated in PTC cells by proliferation assay. TPC-1, BCPAP, and FRTL-5 control cells were grown with or without $10 \mathrm{ng} / \mathrm{ml}$ of TGF $\beta 1$, and counted at time 0 and at $48 \mathrm{~h}$. The results, expressed as a percentage of growth inhibition with respect to relative untreated control, showed that TPC-1 was significantly inhibited by $32 \%(P<0 \cdot 05)$, BCPAP was inhibited only by $8 \%$, and FRTL-5 was highly significantly inhibited by $72 \%$ $(P<0 \cdot 001$; Fig. 6A). Therefore, BCPAP was resistant to the TGF $\beta$-mediated growth inhibition, while TPC-1 showed a significant inhibition of proliferation, although lower than FRTL-5.

To investigate the role of SMAD4 in the control of cell growth, we performed proliferation assay on cells overexpressing SMAD4. TPC-1 and BCPAP, transiently transfected with GFP-tagged SMAD4 wt or with the empty vector, were counted at time 0 , at $24 \mathrm{~h}$, and at $48 \mathrm{~h}$ in the presence or in the absence of $10 \mathrm{ng} / \mathrm{ml}$ of TGF $\beta 1$. In basal conditions, SMAD4 overexpression did not cause a significant difference in growth rate when comparing SMAD4-transfected cells to empty vector-transfected cells (Fig. $6 \mathrm{~B}$ and $\mathrm{C}$ ). TGF $\beta 1$ treatment, instead, determined a considerable reduction of proliferation.
In TPC-1, the inhibition of proliferation was significant $(P<0 \cdot 05)$ at $24 \mathrm{~h}(59 \%)$ and highly significant $(P<0 \cdot 001)$ at $48 \mathrm{~h}(71 \%)$, while in the cells transfected with empty vector, the inhibition was $19 \%$ at $24 \mathrm{~h}$ and $35 \%$ at $48 \mathrm{~h}(P<0.05)$, as in untransfected cells (Fig. 6D). The results obtained in BCPAP overexpressing SMAD4 demonstrated a significant $(P<0.05)$ recovery of TGF $\beta$-mediated inhibition of proliferation only at $48 \mathrm{~h}(23 \%)$, when compared to the empty vector-transfected cells (6\%; Fig. 6E). Student's $t$-test, which was performed comparing the percentage of growth inhibition of SMAD4-transfected PTC cell lines versus empty vector-transfected cells, demonstrated a significant increase $(P<0 \cdot 05)$ at $24 \mathrm{~h}, 59$ vs $19 \%$, and a highly significant increase $(P<0 \cdot 001)$ at $48 \mathrm{~h}, 71$ vs $35 \%$, in TPC-1, and it also demonstrated a significant increase $(P<0.05)$ only at $48 \mathrm{~h}, 23$ vs $6 \%$, in BCPAP. The trypan blue test performed in all proliferation assays (data not shown) demonstrated that the growth inhibition observed in these cells was not due to reduction of cellular viability.

The above results provided evidence that the overexpression of SMAD4 caused a strong increase of the antiproliferative effect of TGF $\beta$ in human PTC cell lines.

\section{SMAD4 overexpression in the control of migratory behavior of TPC-1 and BCPAP}

Migration of tumor cells has an important role in specific processes for metastases formation (Chiang \& Massagué 2008). The ability of TPC-1 and BCPAP to migrate was studied through the wound-healing assay. The experiments were performed in basal condition and after transient transfection either with pEGFPC3-SMAD4 wt or with pEGFPC3 empty vector. 
A

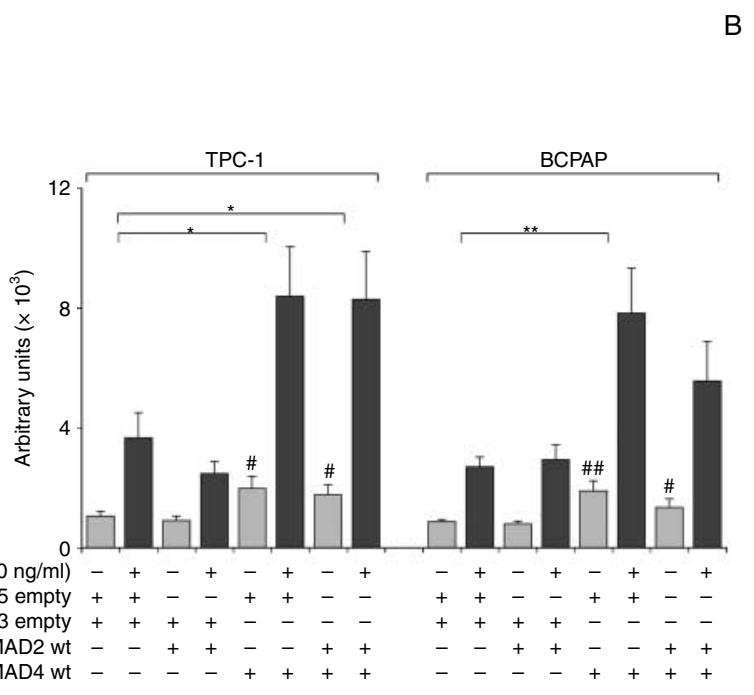

B
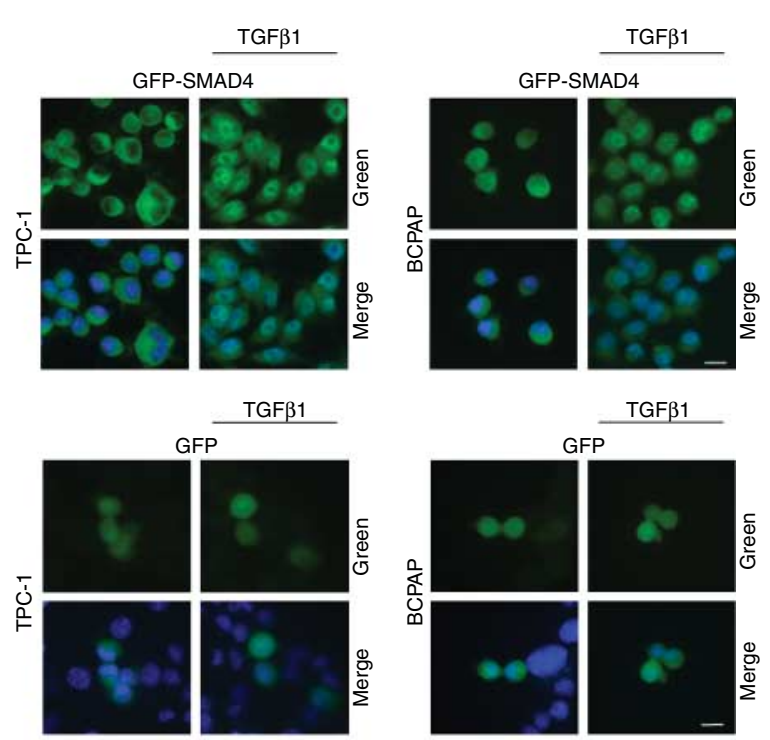

。

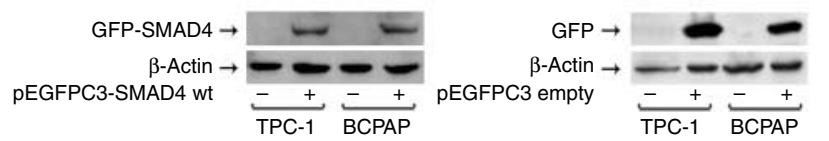

Figure 5 TGF $\beta$ signaling in TPC-1 and BCPAP overexpressing SMAD4. (A) TPC-1 and BCPAP overexpressing SMAD4 wt and/or SMAD2 wt were transiently transfected with 3TP-Lux reporter. Cells were stimulated with $10 \mathrm{ng} / \mathrm{ml}$ of TGF $\beta 1 \mathrm{for} 24 \mathrm{~h}$, and the luciferase activity was expressed as arbitrary units. \# and \#\# indicate a statistical significance $(P<0.05$ and $P<0.001$ respectively, $P$ value referred to Student's $t$-test) of TPC-1 and BCPAP overexpressing SMAD4 versus cells transfected with reporter construct. ${ }^{*}$ and ${ }^{* *}$ indicate a statistical significance $(P<0.05$ and $P<0.001$ respectively, $P$ value referred to $F$ value, Fisher test across groups $)$ of cells transfected with SMAD4 versus cells transfected with reporter construct and SMAD4-/SMAD2-cotransfected cells versus cells transfected with reporter construct. Each result is the mean of four independent experiments in triplicate \pm S.E.M.

(B) Immunofluorescence assays of GFP-tagged SMAD4 protein in TPC-1 and BCPAP overexpressing GFP-tagged SMAD4 wt and cells transfected with empty vector, treated or untreated with $10 \mathrm{ng} / \mathrm{ml}$ of TGF $\beta 1$ for $1 \mathrm{~h}$. Scale bar, $20 \mu \mathrm{m}$. (C) Representative western blots performed using specific antibody anti-GFP in total extracts from transiently transfected cells.

The cells were grown to confluence in monolayers, and their ability to migrate into and across a denuded area of the monolayer has been evaluated after $24 \mathrm{~h}$. As shown in Fig. 7A, TPC-1 and BCPAP had a highly significant $(P<0.001)$ migratory attitude, compared to the FRTL-5, which migrated quite slowly. The overexpression of SMAD4 strongly reduced the migratory behavior of these cells (Fig. 7B). The analysis of the data demonstrated that over a $24 \mathrm{~h}$ time course, TPC-1 overexpressing SMAD4 consistently migrated at a slower rate $(21 \%$; $P<0 \cdot 001)$ than empty vector control cells $(50 \%)$. BCPAP overexpressing SMAD4 showed a similar behavior, migrating at a slower rate $(14 \% ; P<0 \cdot 001)$ than empty vector control cells $(38 \%)$. Stimulation with TGF $\beta 1$ did not cause any significant modification in motility in transfected cells, since SMAD4 overexpression alone was responsible for maximal activation of SMAD signaling (Fig. 7B). The inhibition of migration at $24 \mathrm{~h}$ was independent of the proliferative response because the overexpression of SMAD4 did not influence the growth rate in the same gap (Fig. 6B and C).
It has been demonstrated that E-cadherin and $\mathrm{N}$-cadherin have an important role in progressionpromoting pathway in invasive and migratory behavior in many human carcinomas (Christofori 2006, Shiou et al. 2007). The expression levels of E-cadherin and $\mathrm{N}$-cadherin have been evaluated performing western blot analyses on total lysates of TPC-1, BCPAP, FTC133, and FRTL-5. MCF7 has been used as a positive control of E-cadherin and a negative control of N-cadherin; HEK293, instead, has been used as a positive control of $\mathrm{N}$-cadherin and a negative control of E-cadherin (Hogan et al. 2004). The results obtained demonstrated that E-cadherin expression was lower in PTC cell lines with respect to FTC133, and $\mathrm{N}$-cadherin expression was comparable in all thyroid carcinoma cell lines (Fig. 7C). TPC-1 and BCPAP overexpressing $S M A D 4$ showed a highly significant $(P<0 \cdot 001)$ increase of the E-cadherin level (Fig. 7D).

In conclusion, our results strongly supported that, in thyroid papillary carcinomas, the overexpression of SMAD4 was responsible both for the increase of antiproliferative effect of TGF $\beta$ and for the reduction of cellular motility in vitro. 


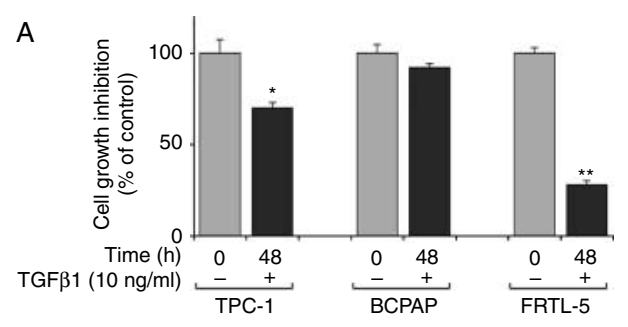

B

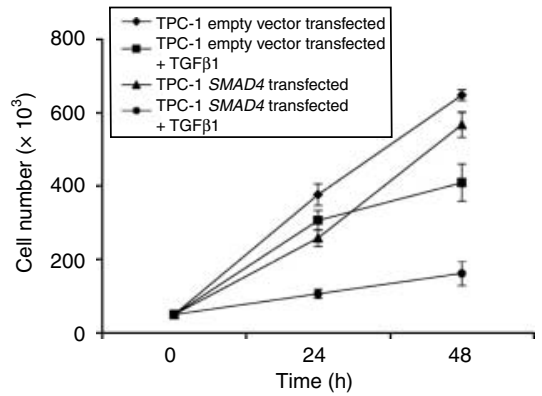

D

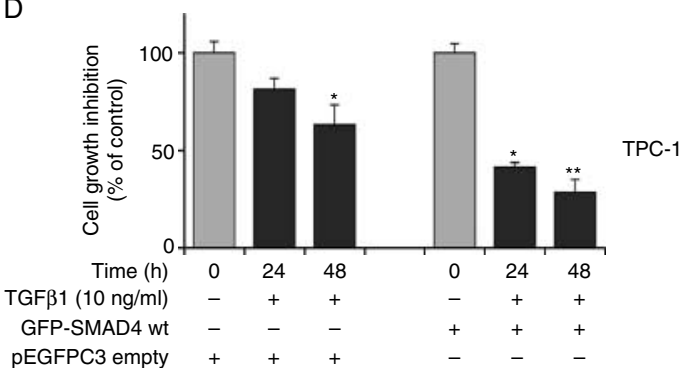

C

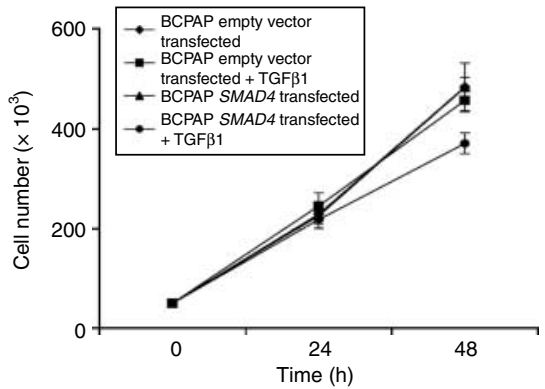

E

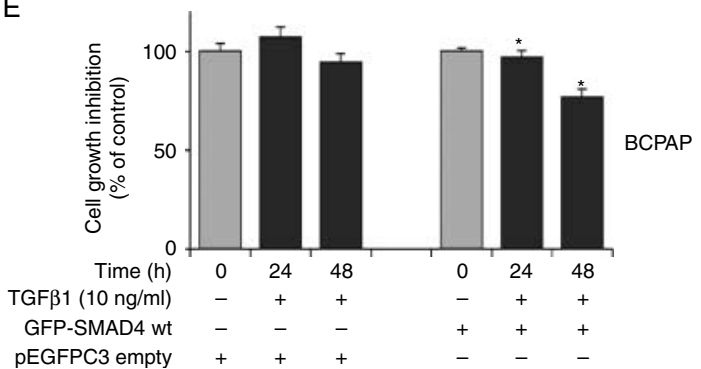

Figure 6 Effect of TGF $\beta 1$ on cell growth in thyroid cell lines. (A) Cells were grown in the presence or the absence of $10 \mathrm{ng} / \mathrm{ml}$ of TGF $\beta 1$ for $48 \mathrm{~h}$ and were counted three times by two independent investigators. Inter-observer variation was below $5 \%$. Values represent the mean of triplicate determination \pm s.D. of three experiments, and the results were expressed as a percentage of growth inhibition ( ${ }^{*}$ and ${ }^{* *}$ indicate a statistical significance (Student's $t$-test), $P<0.05$ and $P<0.001$ respectively) of treated versus untreated cells. ( $B$ and $C)$ Cells transiently transfected with GFP-tagged SMAD4 wt or with the empty vector, grown in the presence or the absence of $10 \mathrm{ng} / \mathrm{ml}$ of TGF $\beta 1$ for 24 and $48 \mathrm{~h}$, were counted three times by two independent investigators. Inter-observer variation was below $5 \%$. Values represent the mean of triplicate determination \pm S.D. of three experiments. ( $D$ and $E)$ Histograms of the results expressed as a percentage of growth inhibition ( ${ }^{*}$ and ${ }^{* *}$ indicate a statistical significance (Student's $t$-test), $P<0.05$ and $P<0.001$ respectively).

\section{SMAD4 expression in human PTCs}

To investigate whether the findings observed in cell lines were relevant to human thyroid carcinogenesis, a group of 23 human PTCs were examined for SMAD4 expression by immunohistochemistry and compared to normal tissues from the opposite lobe. Our results showed that 7 out of $23(30 \%)$ PTC tumor samples, including 1 case of follicular variant of PTCs (Fig. 8), presented a weak and focal intensity of SMAD4 staining with SMAD4-negative areas compared to normal tissue, where a diffuse staining of SMAD4 was observable. In remaining samples, SMAD4 expression appeared to be retained and comparable to the normal tissues. This result was consistent with the data obtained in PTC cell lines, outlining the important role of SMAD4 in thyroid carcinogenesis.

\section{Discussion}

It is known that a lack of response to TGF $\beta$ inhibitory action in thyroid cells may lead to a loss of controlled growth and is responsible for some cases of multinodular thyroid goiter (Grubeck-Loebenstein et al. 1989, Bidey et al. 1999). In the last year, the role of TGF $\beta$ in the thyroid carcinogenesis has received a significant attention. Experimental evidences demonstrate that thyroid cancer cells can escape to tumorsuppressive action of TGF $\beta$ for the quantitative reduction of receptors and transduction elements. In a model of KRAS-transformed rat thyroid cells, the overexpression of T $\beta$ RII reverts their malignant phenotype and strongly reduces the number of metastases, when transplanted in athymic nude mice 
A
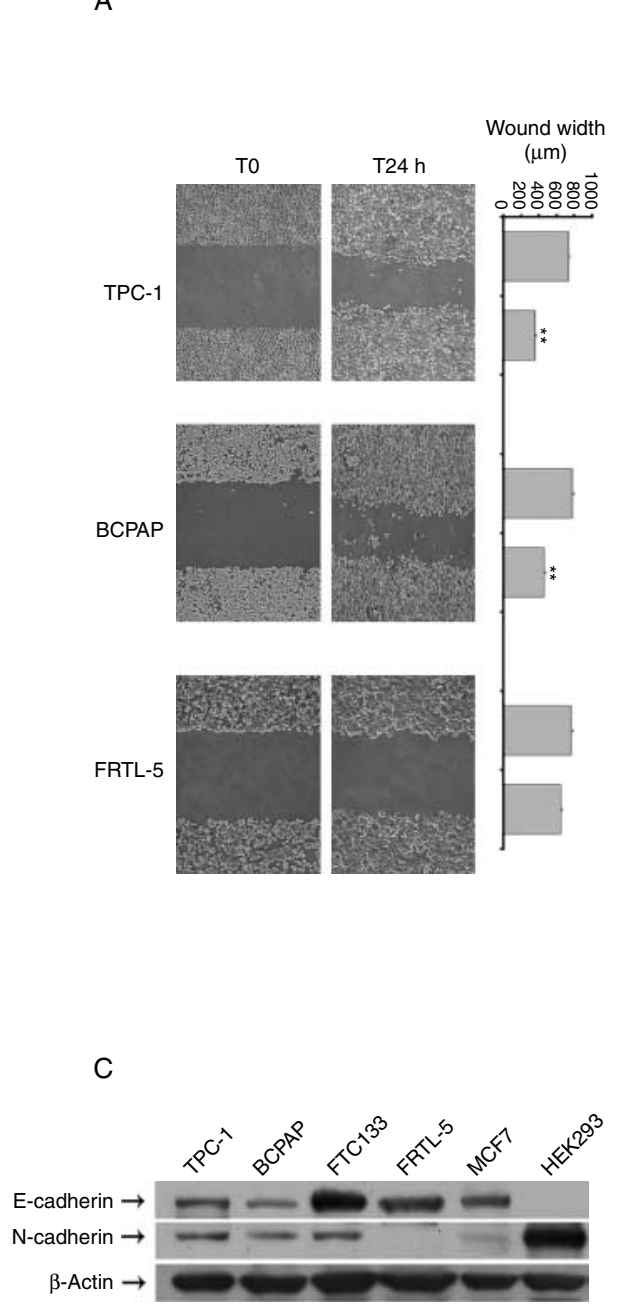

B

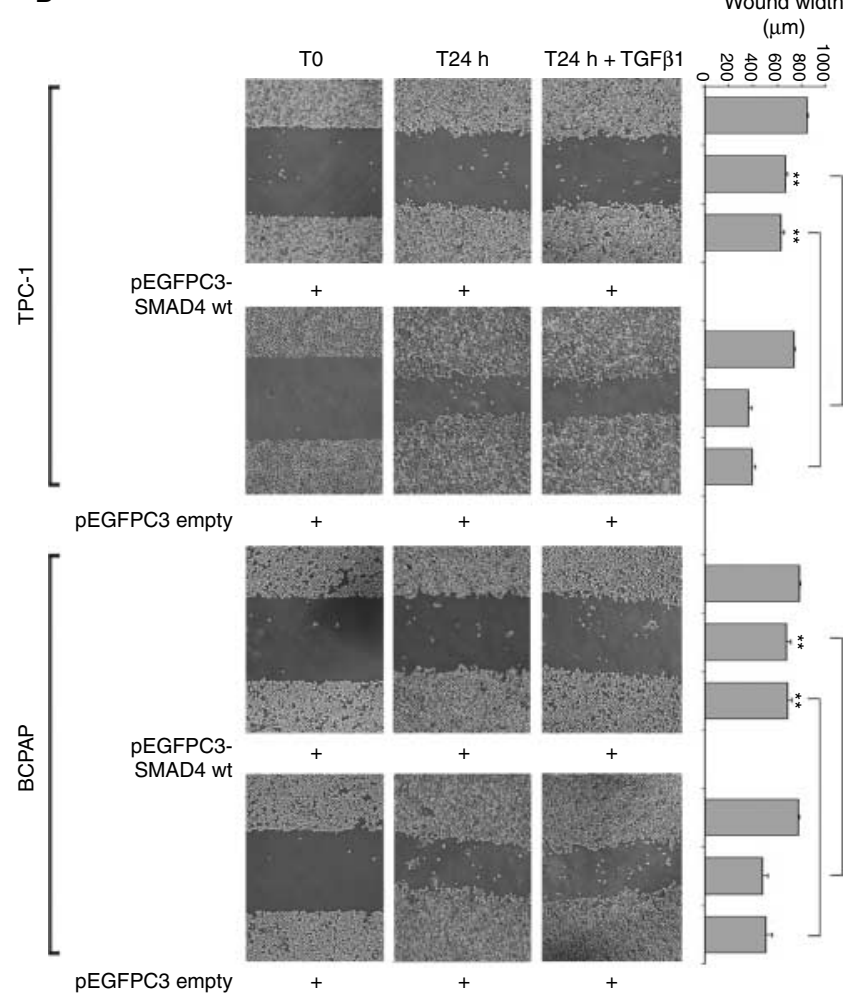

D

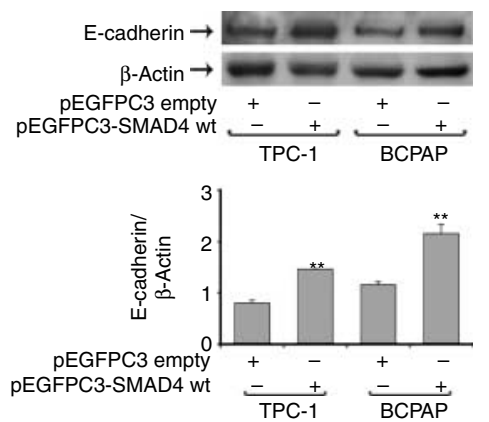

Figure 7 Migratory behavior of TPC-1 and BCPAP. (A) Wound-healing assay was performed in confluent monolayers for $24 \mathrm{~h}$, and the extension of the area colonized by the cells was estimated using Axio Vision, Zeiss software (** indicates a statistical significance (Student's $t$-test, $P<0.001$ ) compared to FRTL-5). (B) Wound-healing assay in TPC-1 and BCPAP overexpressing SMAD4 wt, untreated or treated with $10 \mathrm{ng} / \mathrm{ml}$ of TGF $\beta 1$ for $24 \mathrm{~h}$ (** indicates a high statistical significance (Student's $t$-test, $P<0.001)$ compared to empty vector control cells). Images are representative of three separate experiments. (C) Whole protein lysates (40 $\mu \mathrm{g} / \mathrm{lane}$ ) from TPC-1, BCPAP, FTC133, and FRTL-5 control cells, MCF7, and HEK293, were analyzed by western blot using antibodies against E-cadherin and N-cadherin. (D) Western blot of whole protein lysates $(40 \mu \mathrm{g} / \mathrm{lane})$ from TPC-1 and BCPAP transiently transfected with pEGFPC3-SMAD4 wt or pEGFPC3 empty vector performed using an antibody against E-cadherin. Bottom, densitometric evaluation of the E-cadherin bands normalized to the levels of $\beta$-actin ( ${ }^{\star *}$ indicates a high statistical significance (Student's $t$-test), $P<0 \cdot 001$ ).

(Turco et al. 1999). A deregulated expression with a reduced TBRII RNA level has been identified in a large number of thyroid carcinomas and correlates with a more undifferentiated histotype (Lazzereschi et al. 1997). Moreover, mutations and/or imbalances in expression due to alternative RNA splicing and altered localization of the SMAD4 protein have been demonstrated in a large group of thyroid cancer with different histotypes (Lazzereschi et al. 2005). It is known that TGFß's role in human cancer appears both complex and context dependent. Depending on the tumor type and the stage of tumor progression, it can exhibit strong tumor-suppressive or tumor-promoting functions. More recently, it has been demonstrated that 

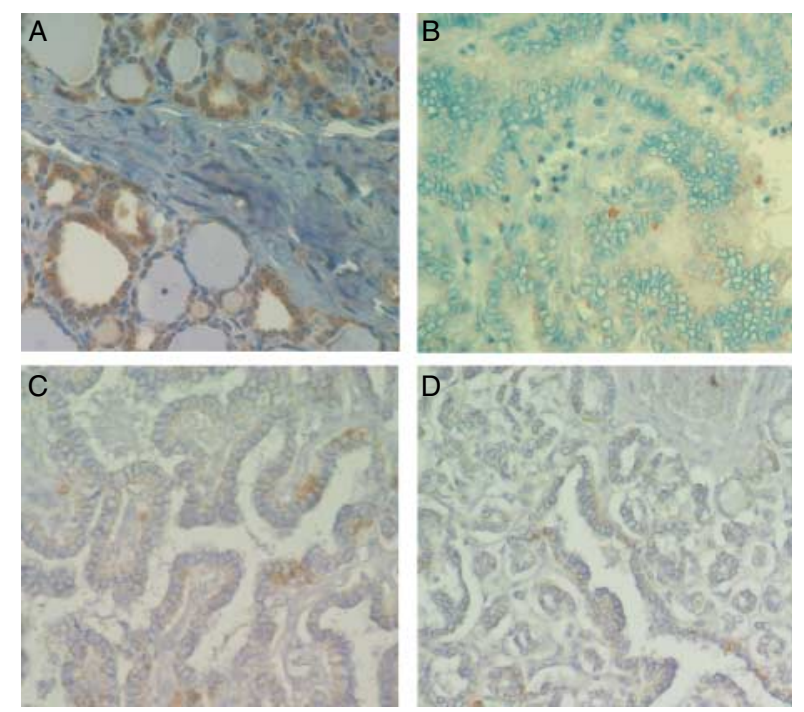

Figure 8 SMAD4 expression in human papillary carcinomas. Immunohistochemistry, using antibody against SMAD4, was performed in thyroid samples from normal tissue $(A)$, primary PTCs (B and C), and in one case of PTC follicular variant (D). Original magnification was $150 \times(A-C)$ and $100 \times(D)$.

also in thyroid cells, as well as in the skin tumors, or in metastatic colon cancer (Padua \& Massagué 2009), TGF $\beta$ can acts as a tumor-promoting factor. The expression of BRAF V600E in normal rat thyrocytes and in 50 cases of human PTCs determines a reduction of NIS expression and an increase of TGF $\beta$ secretion, suggesting an iperactivation of TGF $\beta$ signaling, responsible for the pro-tumorigenic activity (RiescoEizaguirre et al. 2009).

The present study focuses on the role of TGF $\beta$ pathway as tumor suppressor in two human PTC cell lines, TPC-1 and BCPAP, and in a group of 23 cases of human papillary carcinomas. In PTC cells, which were widely used by different groups (Baldini et al. 2004, Motti et al. 2005, Meireles et al. 2007, Visone et al. 2007, Schweppe et al. 2008, Salerno et al. 2010), we have studied the TGF $\beta$ pathway, demonstrating that the hypoexpression of SMAD4 protein is responsible for alteration in TGF $\beta$ signal transduction, as supported by the strong reduction of transcriptional activity of 3TPLux. The p3TP-Lux reporter is most commonly used to measure TGF $\beta$ responsiveness (Wrana et al. 1992, Carcamo et al. 1994). SMAD4 has been shown to be required for this transcriptional activity, since SMAD4deficient cell lines are not responsive but can be rescued with SMAD4 expression (Lagna et al. 1996, de Caestecker et al. 1997). The reduction of 3TP-Lux activity observed in PTC cell lines could be explained by the low threshold of activation of TGF $\beta$ signaling, depending on T $\beta R I$ or SMAD levels (Yingling et al. 1995). The TRRI level in TPC-1 and in BCPAP is lower than the control cells, but the ability of the receptor to phosphorylate SMAD2 and SMAD3 is fully maintained, as demonstrated in Fig. 1B and C. The stability of TBRI represents an important regulatory mechanism for TGF $\beta$ signaling, both in cell culture studies and in vivo models. TGF $\beta$ receptors are ubiquitinated and degraded through the action of several cooperating protein complexes containing E3 ligases, as well as other important regulators of protein degradation. The I-SMADs seem to have an important role in regulating many of these complexes, orchestrating both ubiquitination and de-ubiquitination (Lönn et al. 2009). The levels of SMURF1 and SMAD7, overexpressed in the anaplastic thyroid carcinoma cell line (Cerutti et al. 2003), are also unaltered in our model. Therefore, the lower level of T $\beta$ RI observed in PTC cell lines cannot be attributed to SMAD7 and SMURF1 alterations. However, whether the receptors are degraded via the lysosomes, proteasomes or via both of these pathways is still an open question (Lönn et al. 2009). Thus, the hypoexpression of SMAD4 is responsible for the reduction of the threshold of induction of the signaling cascade, resulting in partial loss of TGF $\beta$-transcriptional response. In fact, the overexpression of SMAD4 significantly increases the transcriptional stimulation of 3TP-Lux in the absence or in the presence of TGF $\beta 1$ treatment. Altogether, these data demonstrate that, despite the lower level of T $\beta R I$, the hypoexpression of SMAD4 is mainly responsible for the impairment of TGF $\beta$ signaling.

Since we previously demonstrated that SMAD4 mutations are frequent in PTCs (Lazzereschi et al. 2005), sequencing of the entire coding part of the $S M A D 4$ gene was performed. It did not find any mutations in the SMAD4 gene; also mRNA levels are not modified; consequently, the alteration responsible for the hypoexpression of SMAD4 protein does not involve the transcriptional mechanism. Our data, in agreement with Heldin et al. (1999), led us to hypothesize that the cause of hypoexpression could be found in alteration of major components of translational machinery, which are frequently altered in human neoplasms (Rosenwald 2004). Moreover, recent observations demonstrate an important role of microRNA in the development of a wide range of human diseases, including cancer. Therefore, in our cells, we could hypothesize an alternative mechanism in the regulation of SMAD4 levels, involving an alteration in miRNA expression profiles (Erson \& Petty 2008).

One of the important effects of SMAD4 hypoexpression in TPC-1 and BCPAP is the drastic reduction of nuclear accumulation of this protein. The molecular mechanism that controls subcellular localization and activation of SMAD proteins is crucial for TGF $\beta$ signaling, and it is not yet fully clarified. SMAD4 accumulates in the nucleus by association with activated R-SMADs (Liu et al. 1997, Hoodless et al. 1999, 
Watanabe et al. 2000). However, SMAD4 also undergoes continuous nucleocytoplasmic shuttling on its own, independently of TGF $\beta$ signaling (Pierreux et al. 2000, Watanabe et al. 2000, Hill 2009). Our results demonstrate that the SMAD4 ability to translocate into the nucleus is preserved, and the weak cellular fluorescence signal observed in TPC-1 and in BCPAP was due to the hypoexpression of this protein. Work over the past few years has emphasized the importance of SMAD nucleocytoplasmic shuttling in TGF $\beta$ signaling regulation. Tumorigenic SMAD4 alterations, as demonstrated in pancreatic human cancer, can eliminate nuclear accumulation of SMAD4, suggesting that defects in nuclear import may contribute to tumorigenicity (Morén et al. 2000). The overexpression of SMAD4 in TPC-1 and in BCPAP clearly reinstates the translocation of SMAD4 from the cytoplasm to the nucleus. The levels and the duration of residence in the nucleus of SMAD4 are important events for the response to TGF $\beta$ in the cells. Consistent with the notion that TGF $\beta$ can act as a morphogen that induces distinct cell fates along a concentration gradient in embryonic development, many studies demonstrate that the intensity and duration of the TGFß-SMAD response are important determinants for signaling specificity and, therefore, the activity of SMADs is carefully regulated (Gurdon \& Bourillot 2001, Hill 2001, ten Dijke \& Hill 2004). Enhanced proteasomal degradation of SMAD4 is responsible for TGF $\beta$ resistance in breast cancer (Dupont et al. 2005). In our cells, the ability of proteasome to degrade SMAD4 is maintained and comparable to that of control cells. Therefore, different mechanisms of protein degradation seem to be involved.

Lack of responsiveness to TGF $\beta$ antiproliferative effects is a hallmark for the cancer, where TGF $\beta$ and its pathway function as oncosuppressors. Our data show that BCPAP is resistant to growth inhibition of TGF $\beta$, while TPC- 1 , in accordance with the data of Matsuo et al. (2006), is still sensitive to its antiproliferative response, although lower than control cells. Here, we demonstrate that the level of SMAD4 protein is low both in TPC-1 and in BCPAP, and it is responsible for the weakening of TGF $\beta$ responsiveness in these cell lines. The overexpression of SMAD4 significantly increases the TGF $\beta$ growth inhibition in TPC-1 and partially restores this response in BCPAP. We think that the behavior observed in BCPAP could be caused by the different genetic and molecular profile, recently well characterized in these cell lines (Meireles et al. 2007, Schweppe et al. 2008).

Although the majority of thyroid cancers have an excellent prognosis, there are a small percentage of cases that show an extensive local invasion and distant metastases, which frequently do not respond to standard treatments and have a worsened prognosis.
The genetic basis for thyroid cancer initiation and development is well characterized. It has been demonstrated that the activation of oncogenes like $R A S$, $B R A F, R E T / P T C$, and PI3K/AKT plays an important role in thyroid tumorigenesis (Vasko et al. 2007), but the molecular mechanism involved in the thyroid cancer invasion needs clarification. The acquisition of a migratory phenotype is an essential property of invading and metastasizing cancer cells. TPC-1 and BCPAP cells have a strong and significant ability to migrate (Sancho et al. 2006, Scarpino et al. 2007). Genetic data indicate that loss of SMAD4 in cancer cells may correlate not only with the specific loss of TGF $\beta$ cytostatic response, but also with acquisition of an invasive phenotype (Takaku et al. 1998). In SW480 colon carcinoma cells, the re-expression of SMAD4 results in loss of tumorigenicity in nude mice, and is accompanied by the restoration of a more epithelioid morphology and induction of E-cadherin (Müller et al. 2002, Tian et al. 2009). Here, we demonstrate that the overexpression of SMAD4 in PTC cell lines induces a strong suppression of motility, as well as a significant increase of E-cadherin expression, indicating that the level of SMAD4 is a critical regulator of these processes.

Finally, our results obtained in the model in vitro are strongly supported by the preliminary finding that $30 \%$ of human PTCs, examined by immunohistochemistry, show a strong reduction of the SMAD4 staining.

All together, our data demonstrate that the level of SMAD4 protein plays an important role in thyroid carcinogenesis; although the mechanism by which tumor cells achieve this hypoexpression needs further investigation, we think it could be considered as a new possible therapeutic target for thyroid cancer.

\section{Declaration of interest}

The authors declare that there is no conflict of interest that could be perceived as prejudicing the impartiality of the research reported.

\section{Funding}

This work was supported by the Ministero Italiano dell'Università e della Ricerca (PRIN 2007) and by the Associazione Italiana Ricerca sul Cancro (AIRC).

\section{Acknowledgements}

We thank Prof. Liliana Attisano for plasmids, Prof. Alfredo Fusco for TPC-1 and BCPAP cell lines, and Prof. Salvatore Ulisse for FTC133 cell line. The authors would also like to thank Mr Daniel Kenton for the careful revisions made. This work is dedicated to the memory of Prof. Giulia Colletta. 


\section{References}

Ambesi-Impiombato FS, Parks L \& Coon HG 1980 Culture of hormone dependent functional epithelial cells from rat thyroids. PNAS 77 3455-3459. (doi:10.1073/pnas.77.6.3455)

Attisano L \& Wrana JL 2000 Smads as transcriptional co-modulators. Current Opinion in Cell Biology 12 235-243. (doi:10.1016/S09550674(99)00081-2)

Baldini E, Toller M, Graziano FM, Russo FP, Pepe M, Biordi L, Marchioni E, Curcio F, Ulisse S, Ambesi-Impiombato FS et al. 2004 Expression of matrix metalloproteinases and their specific inhibitors in normal and different human thyroid tumor cell lines. Thyroid 14 881-888. (doi:10.1089/thy.2004.14.881)

Bidey SP, Hill DJ \& Eggo MC 1999 Growth factors and goitrogenesis. Journal of Endocrinology 160 321-332. (doi:10.1677/joe.0.1600321)

de Caestecker MP, Hemmati P, Larisch-Bloch S, Ajmera R, Roberts AB \& Lechleider RJ 1997 Characterization of functional domains within Smad4/DPC4. Journal of Biological Chemistry 272 13690-13696. (doi:10.1074/jbc.272.21.13690)

Carcamo J, Weis FM, Ventura F, Wieser R, Wrana JL, Attisano L \& Massagué J 1994 Type I receptors specify growth-inhibitory and transcriptional responses to TGF- $\beta$ and activin. Molecular and Cellular Biology 14 3810-3821.

Carneiro C, Alvarez CV, Zalvide J, Vidal A \& Domínguez F 1998 TGF- $\beta 1$ actions on FRTL-5 cells provide a model for the physiological regulation of thyroid growth. Oncogene 16 1455-1465. (doi:10.1038/ sj.onc.1201662)

Cerutti JM, Ebina KN, Matsuo SE, Martins L, Maciel RM \& Kimura ET 2003 Expression of Smad4 and Smad7 in human thyroid follicular carcinoma cell lines. Journal of Endocrinological Investigation 26 $516-521$.

Chiang AC \& Massagué J 2008 Molecular basis of metastasis. New England Journal of Medicine 359 2814-2823. (doi:10.1056/ NEJMra0805239)

Christofori G 2006 New signals from the invasive front. Nature $\mathbf{4 4 1}$ 444-450. (doi:10.1038/nature04872)

Colletta G, Cirafici AM \& Di Carlo A 1989 Dual effect of transforming growth factor $\beta$ on rat thyroid cells: inhibition of thyrotropininduced proliferation and reduction of thyroid-specific differentiation markers. Cancer Research 49 3457-3462.

Coppa A, Mincione G, Mammarella S, Ranieri A \& Colletta G 1995 Epithelial rat thyroid cell clones, escaping from transforming growth factor $\beta$ negative growth control, are still inhibited by this factor in the ability to trap iodide. Cell Growth and Differentiation 6 281-290.

Costamagna E, Garcia B \& Santisteban P 2004 The functional interaction between the paired domain transcription factor Pax8 and Smad 3 is involved in transforming growth factor- $\beta$ repression of the sodium/iodide symporter gene. Journal of Biological Chemistry 279 3439-3446. (doi:10.1074/jbc.M307138200)

Depoortere F, Pirson I, Bartek J, Dumont JE \& Roger PP 2000 Transforming growth factor $\beta(1)$ selectively inhibits the cyclic AMP-dependent proliferation of primary thyroid epithelial cells by preventing the association of cyclin D3-cdk4 with nuclear p27(kip1). Molecular Biology of the Cell 11 1061-1076.

ten Dijke P \& Hill CS 2004 New insights into TGF- $\beta$-Smad signalling. Trends in Biochemical Sciences 29 265-273. (doi:10.1016/j.tibs.2004. 03.008)

Dupont S, Zacchigna L, Cordenonsi M, Soligo S, Adorno M, Rugge M \& Piccolo S 2005 Germ-layer specification and control of cell growth by Ectodermin, a Smad4 ubiquitin ligase. Cell 121 87-99. (doi:10. 1016/j.cell.2005.01.033)

Erson AE \& Petty EM 2008 MicroRNAs in development and disease. Clinical Genetics 74 296-306. (doi:10.1111/j.1399-0004.2008.01076.x)

Franzén Å, Piek E, Westermark B, ten Dijke P \& Heldin NE 1999 Expression of transforming growth factor- $\beta 1$, activin A, and their receptors in thyroid follicle cells: negative regulation of thyrocyte growth and function. Endocrinology 140 4300-4310. (doi:10.1210/ en.140.9.4300)

Goretzki PE, Frilling A, Simon D \& Roeher HD 1990 Growth regulation of normal thyroids and thyroid tumors in man. Recent Results in Cancer Research 118 48-63.

de Groot RP \& Kruijer W 1990 Transcriptional activation by TGF $\beta 1$ mediated by the dyad symmetry element (DSE) and the TPA responsive element (TRE). Biochemical and Biophysical Research Communications 168 1074-1081. (doi:10.1016/0006291X(90)91139-J)

Grubeck-Loebenstein B, Buchan G, Sadeghi R, Kissonerghis M, Londei M, Turner M, Pirich K, Roka R, Niederle B, Kassal H et al. 1989 Transforming growth factor $\beta$ regulates thyroid growth. Role in the pathogenesis of nontoxic goiter. Journal of Clinical Investigation 83 764-770. (doi:10.1172/JCI113955)

Gurdon JB \& Bourillot PY 2001 Morphogen gradient interpretation. Nature 413 797-803. (doi:10.1038/35101500)

Heldin NE, Bergström D, Hermansson A, Bergenstråhle A, Nakao A, Westermark B \& ten Dijke P 1999 Lack of responsiveness to TGF- $\beta 1$ in a thyroid carcinoma cell line with functional type I and type II TGF- $\beta$ receptors and Smad proteins, suggests a novel mechanism for TGF- $\beta$ insensitivity in carcinoma cells. Molecular and Cellular Endocrinology 153 79-90. (doi:10.1016/S0303-7207(99)00086-6)

Hill CS 2001 TGF- $\beta$ signalling pathways in early Xenopus development. Current Opinion in Genetics and Development 11 533-540. (doi:10.1016/ S0959-437X (00) 00229-X)

Hill CS 2009 Nucleocytoplasmic shuttling of Smad proteins. Cell Research 19 36-46. (doi:10.1038/cr.2008.325)

Hogan C, Serpente N, Cogram P, Hosking CR, Bialucha CU, Feller SM, Braga VM, Birchmeier W \& Fujita Y 2004 Rap1 regulates the formation of E-cadherin-based cell-cell contacts. Molecular and Cellular Biology 24 6690-6700. (doi:10.1128/MCB.24.15. 6690-6700.2004)

Hoodless PA, Tsukazaki T, Nishimatsu S, Attisano L, Wrana JL \& Thomsen GH 1999 Dominant-negative Smad2 mutants inhibit activin/Vg1 signaling and disrupt axis formation in Xenopus. Developmental Biology 207 364-379. (doi:10.1006/dbio.1998.9168)

Imamura T, Takase M, Nishihara A, Oeda E, Hanai J, Kawabata M \& Miyazono K 1997 Smad6 inhibits signalling by the TGF- $\beta$ superfamily. Nature 389 622-626. (doi:10.1038/39355)

Iuliano R, Trapasso F, Le Pera I, Schepis F, Sama I, Clodomiro A, Dumon KR, Santoro M, Chiariotti L, Viglietto G et al. 2003 An adenovirus carrying the rat protein tyrosine phosphatase eta suppresses the growth of human thyroid carcinoma cell lines in vitro and in vivo. Cancer Research 63 882-886.

Keeton MR, Curriden SA, van Zonneveld AJ \& Loskutoff DJ 1991 Identification of regulatory sequences in the type 1 plasminogen activator inhibitor gene responsive to transforming growth factor $\beta$. Journal of Biological Chemistry 266 23048-23052.

Kimura ET, Kopp P, Zbaeren J, Asmis LM, Ruchti C, Maciel RM \& Studer H 1999 Expression of transforming growth factor $\beta 1, \beta 2$, and $\beta 3$ in multinodular goiters and differentiated thyroid carcinomas: a comparative study. Thyroid 9 119-125. (doi:10.1089/ thy.1999.9.119)

Kogai T, Sajid-Crockett S, Newmarch LS, Liu YY \& Brent GA 2008 Phosphoinositide-3-kinase inhibition induces sodium/iodide symporter expression in rat thyroid cells and human papillary thyroid cancer cells. Journal of Endocrinology 199 243-252. (doi:10.1677/JOE08-0333)

Lagna G, Hata A, Hemmati-Brivanlou A \& Massagué J 1996 Partnership between DPC4 and SMAD proteins in TGF- $\beta$ signalling pathways. Nature 383 832-836. (doi:10.1038/383832a0)

Lazzereschi D, Ranieri A, Mincione G, Taccogna S, Nardi F \& Colletta G 1997 Human malignant thyroid tumors displayed reduced levels of transforming growth factor $\beta$ receptor type II messenger RNA and protein. Cancer Research 57 2071-2076. 
Lazzereschi D, Nardi F, Turco A, Ottini L, D'Amico C, MarianiCostantini R, Gulino A \& Coppa A 2005 A complex pattern of mutations and abnormal splicing of Smad4 is present in thyroid tumours. Oncogene 24 5344-5354. (doi:10.1038/sj.onc.1208603)

Liu F, Pouponnot C \& Massagué J 1997 Dual role of the Smad4/DPC4 tumor suppressor in TGF $\beta$-inducible transcriptional complexes. Genes and Development 11 3157-3167. (doi:10.1101/gad.11.23.3157)

Lönn P, Morén A, Raja E, Dahl M \& Moustakas A 2009 Regulating the stability of TGF $\beta$ receptors and Smads. Cell Research 19 21-35. (doi:10.1038/cr.2008.308)

Matsuo SE, Leoni SG, Colquhoun A \& Kimura ET 2006 Transforming growth factor-b1 and activin A generate antiproliferative signaling in thyroid cancer cells. Journal of Endocrinology 190 141-150. (doi:10. 1677/joe.1.06713)

Meireles AM, Preto A, Rocha AS, Rebocho AP, Máximo V, PereiraCastro I, Moreira S, Feijão T, Botelho T, Marques R et al. 2007 Molecular and genotypic characterization of human thyroid follicular cell carcinoma-derived cell lines. Thyroid 17 707-715. (doi:10.1089/thy.2007.0097)

Morén A, Itoh S, Moustakas A, ten Dijke P \& Heldin CH 2000 Functional consequences of tumorigenic missense mutations in the amino-terminal domain of Smad4. Oncogene 19 4396-4404. (doi:10. 1038/sj.onc.1203798)

Morosini P, Taccaliti A, Di Loreto C, Arnaldi G, Faloia E, Giacchetti G \& Mantero F 1994 Transforming growth factor- $\beta 1$ is more expressed in thyroid follicular adenoma than in normal tissue. Journal of Endocrinological Investigation 17 335-340.

Morris JC III, Ranganathan G, Hay ID, Nelson RE \& Jiang NS 1988 The effects of transforming growth factor- $\beta$ on growth and differentiation of the continuous rat thyroid follicular cell line, FRTL-5. Endocrinology 123 1385-1394. (doi:10.1210/endo123-3-1385)

Motti ML, Califano D, Baldassarre G, Celetti A, Merolla F, Forzati F, Napolitano M, Tavernise B, Fusco A \& Viglietto G 2005 Reduced E-cadherin expression contributes to the loss of p27kip1-mediated mechanism of contact inhibition in thyroid anaplastic carcinomas. Carcinogenesis 26 1021-1034. (doi:10.1093/carcin/bgi050)

Müller N, Reinacher-Schick A, Baldus S, van Hengel J, Berx G, Baar A, van Roy F, Schmiegel W \& Schwarte-Waldhoff I 2002 Smad4 induces the tumor suppressor E-cadherin and P-cadherin in colon carcinoma cells. Oncogene 21 6049-6058. (doi:10.1038/sj.onc. 1205766)

Nakao A, Afrakhte M, Morén A, Nakayama T, Christian JL, Heuchel R, Itoh S, Kawabata M, Heldin NE, Heldin CH et al. 1997 Identification of Smad7, a TGF $\beta$-inducible antagonist of TGF- $\beta$ signaling. Nature 389 631-635. (doi:10.1038/39369)

Nicolussi A, D’Inzeo S, Santulli M, Colletta G \& Coppa A 2003 TGF- $\beta$ control of rat thyroid follicular cells differentiation. Molecular and Cellular Endocrinology 207 1-11. (doi:10.1016/S03037207(03)00238-7)

Nicolussi A, D'Inzeo S, Gismondi A \& Coppa A 2006 Reduction of invasive potential in K-ras-transformed thyroid cells by restoring of TGF- $\beta$ pathway. Clinical and Experimental Metastasis 23 237-248. (doi:10.1007/s10585-006-9023-0)

Padua D \& Massagué J 2009 Roles of TGF $\beta$ in metastasis. Cell Research 19 89-102. (doi:10.1038/cr.2008.316)

Pang XP, Hershman JM, Chung M \& Pekary AE 1989 Characterization of tumor necrosis factor- $\alpha$ receptors in human and rat thyroid cells and regulation of the receptors by thyrotropin. Endocrinology 125 1783-1788. (doi:10.1210/endo-125-4-1783)

Patterson GI \& Padgett RW 2000 TGF $\beta$-related pathways. Roles in Caenorhabditis elegans development. Trends in Genetics 16 27-33. (doi:10.1016/S0168-9525(99)01916-2)

Pekary AE \& Hershman JM 1998 Tumor necrosis factor, ceramide, transforming growth factor- $\beta 1$, and aging reduce $\mathrm{Na}^{+} / \mathrm{I}^{-}$symporter messenger ribonucleic acid levels in FRTL-5 cells. Endocrinology 139 703-712. (doi:10.1210/en.139.2.703)
Pierreux CE, Nicolás FJ \& Hill CS 2000 Transforming growth factor $\beta$-independent shuttling of Smad4 between the cytoplasm and nucleus. Molecular and Cellular Biology 20 9041-9054. (doi:10.1128/ MCB.20.23.9041-9054.2000)

Pomérance M, Quillard J, Chantoux F, Young J \& Blondeau JP 2006 High-level expression, activation, and subcellular localization of p38-MAP kinase in thyroid neoplasms. Journal of Pathology 209 298-306. (doi:10.1002/path.1975)

Riesco-Eizaguirre G, Rodríguez I, De la Vieja A, Costamagna E, Carrasco N, Nistal M \& Santisteban P 2009 The BRAFV600E oncogene induces transforming growth factor $\beta$ secretion leading to sodium iodide symporter repression and increased malignancy in thyroid cancer. Cancer Research 69 8317-8325. (doi:10.1158/00085472.CAN-09-1248)

Rosenwald IB 2004 The role of translation in neoplastic transformation from a pathologist's point of view. Oncogene 23 3230-3247. (doi:10.1038/sj.onc.1207552)

Salerno P, De Falco V, Tamburrino A, Nappi TC, Vecchio G, Schweppe RE, Bollag G, Santoro M \& Salvatore G 2010 Cytostatic activity of adenosine triphosphate-competitive kinase inhibitors in BRAF mutant thyroid carcinoma cells. Journal of Clinical Endocrinology and Metabolism 95 450-455. (doi:10.1210/jc.2009-0373)

Sancho M, Vieira JM, Casalou C, Mesquita M, Pereira T, Cavaco BM, Dias S \& Leite V 2006 Expression and function of the chemokine receptor CCR7 in thyroid carcinomas. Journal of Endocrinology 191 229-238. (doi:10.1677/joe.1.06688)

Scarpino S, Di Napoli A, Melotti F, Talerico C, Cancrini A \& Ruco L 2007 Papillary carcinoma of the thyroid: low expression of NCAM (CD56) is associated with downregulation of VEGF-D production by tumour cells. Journal of Pathology 212 411-419. (doi:10.1002/path.2183)

Schutte M, Hruban RH, Hedrick L, Cho KR, Nadasdy GM, Weinstein CL, Bova GS, Isaacs WB, Cairns P, Nawroz H et al. 1996 DPC4 gene in various tumor types. Cancer Research 56 2527-2530.

Schweppe RE, Klopper JP, Korch C, Pugazhenthi U, Benezra M, Knauf JA, Fagin JA, Marlow LA, Copland JA, Smallridge RC et al. 2008 Deoxyribonucleic acid profiling analysis of 40 human thyroid cancer cell lines reveals cross-contamination resulting in cell line redundancy and misidentification. Journal of Clinical Endocrinology and Metabolism 93 4331-4341. (doi:10.1210/ jc.2008-1102)

Shi Y \& Massagué J 2003 Mechanisms of TGF- $\beta$ signaling from cell membrane to the nucleus. Cell 113 685-700. (doi:10.1016/S00928674(03)00432-X)

Shimura H, Suzuki H, Miyazaki A, Furuya F, Ohta K, Haraguchi K, Endo T \& Onaya T 2001 Transcriptional activation of the thyroglobulin promoter directing suicide gene expression by thyroid transcription factor-1 in thyroid cancer cells. Cancer Research 61 3640-3646.

Shiou S, Singh AB, Moorthy K, Datta PK, Washington MK, Beauchamp RD \& Dhawan P 2007 Smad4 regulates claudin-1 expression in a transforming growth factor- $\beta$-independent manner in colon cancer cells. Cancer Research 67 1571-1579. (doi:10.1158/0008-5472.CAN06-1680)

Suzuki C, Murakami G, Fukuchi M, Shimanuki T, Shikauchi Y, Imamura T \& Miyazono K 2002 Smurfl regulates the inhibitory activity of Smad7 by targeting Smad7 to the plasma membrane. Journal of Biological Chemistry 277 39919-39925. (doi:10.1074/jbc. M201901200)

Takaku K, Oshima M, Miyoshi H, Matsui M, Seldin MF \& Taketo MM 1998 Intestinal tumorigenesis in compound mutant mice of both Dpc4 (Smad4) and Apc genes. Cell 92 645-656. (doi:10.1016/ S0092-8674(00)81132-0)

Taton M, Lamy F, Roger PP \& Dumont JE 1993 General inhibition by transforming growth factor $\beta 1$ of thyrotropin and cAMP responses in human thyroid cells in primary culture. Molecular and Cellular Endocrinology 95 13-21. (doi:10.1016/0303-7207(93)90024-E) 
Tian X, Du H, Fu X, Li K, Li A \& Zhang Y 2009 Smad4 restoration leads to a suppression of Wnt/ $\beta$-catenin signaling activity and migration capacity in human colon carcinoma cells. Biochemical and Biophysical Research Communications 380 478-483. (doi:10. 1016/j.bbrc.2009.01.124)

Turco A, Coppa A, Aloe S, Baccheschi G, Morrone S, Zupi G \& Colletta G 1999 Overexpression of transforming growth factor $\beta$-type II receptor reduces tumorigenicity and metastastic potential of K-ras-transformed thyroid cells. International Journal of Cancer 80 85-91. (doi:10.1002/(SICI) 1097-0215 (19990105) 80:1 <85::AID-IJC17 > 3.0.CO;2-P)

Vasko V, Espinosa AV, Scouten W, He H, Auer H, Liyanarachchi S, Larin A, Savchenko V, Francis GL, de la Chapelle A et al. 2007 Gene expression and functional evidence of epithelial to mesenchymal transition in papillary thyroid carcinoma invasion. PNAS 104 2803-2808. (doi:10.1073/pnas.0610733104)

Visconti R, Federico A, Coppola V, Pentimalli F, Berlingieri MT, Pallante P, Kruhoffer M, Orntoft TF \& Fusco A 2007 Transcriptional profile of Ki-Ras-induced transformation of thyroid cells. Cancer Investigation 25 256-266. (doi:10.1080/07357900701206406)

Visone R, Russo L, Pallante P, De Martino I, Ferraro A, Leone V, Borbone E, Petrocca F, Alder H, Croce CM et al. 2007 MicroRNAs (miR)-221 and miR-222, both overexpressed in human thyroid papillary carcinomas, regulate p27Kip1 protein levels and cell cycle. Endocrine-Related Cancer 14 791-798. (doi:10. 1677/ERC-07-0129)

Watanabe M, Masuyama N, Fukuda M \& Nishida E 2000 Regulation of intracellular dynamics of Smad4 by its leucine-rich nuclear export signal. EMBO Reports 1 176-182. (doi:10.1093/embo-reports/ kvd029)

Wrana JL, Attisano L, Carcamo J, Zentella A, Doody J, Laiho M, Wang XF \& Massagué J 1992 TGF $\beta$ signals through a heteromeric protein kinase receptor complex. Cell 71 1003-1014. (doi:10. 1016/0092-8674(92) 90395-S)

Wyllie FS, Dawson T, Bond JA, Goretzki P, Game S, Prime S \& WynfordThomas D 1991 Correlated abnormalities of transforming growth factor- $\beta 1$ response and p53 expression in thyroid epithelial cell transformation. Molecular and Cellular Endocrinology 76 13-21. (doi:10.1016/0303-7207(91)90255-Q)

Yingling JM, Wang XF \& Bassing CH 1995 Signaling by the transforming growth factor- $\beta$ receptors. Biochimica et Biophysica Acta 1242 115-136.

Received in final form 21 June 2010

Accepted 4 August 2010

Made available online as an Accepted Preprint 4 August 2010 